\title{
ESTUDO DOS POSSÍVEIS EFEITOS TÓXICOS DA EXPOSIÇÃO À Solanum lycocarpum EM RATOS ADULTOS E EM SUA PROLE
}

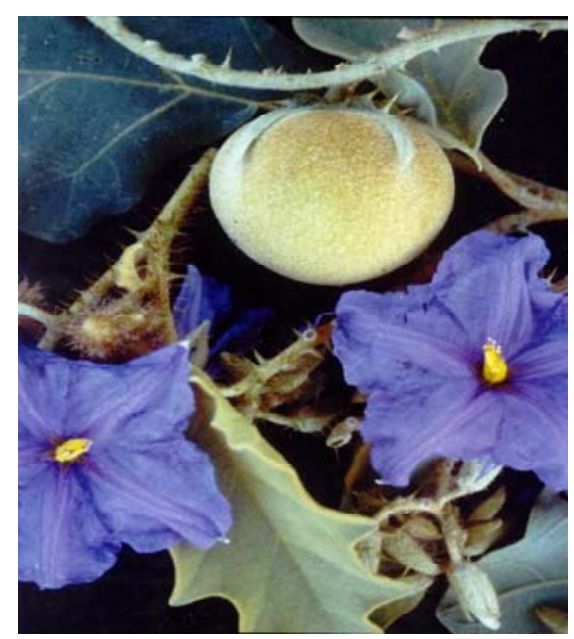

Tese apresentada para obtenção do título de Doutor, junto à Faculdade de Medicina Veterinária e Zootecnia da Universidade de São Paulo

Departamento:

Patologia

Área de concentração:

Patologia Experimental e Comparada

Orientadora:

Profa. Dra. Helenice de Souza Spinosa 
VIVIANE MAYUMI MARUO

\section{ESTUDO DOS POSSÍVEIS EFEITOS TÓXICOS DA EXPOSIÇÃO À}

Solanum lycocarpum EM RATOS ADULTOS E EM SUA PROLE

Tese apresentada para obtenção do título de Doutor, junto à Faculdade de Medicina Veterinária e Zootecnia da Universidade de São Paulo

Departamento:

Patologia

Área de concentração:

Patologia Experimental e Comparada

Orientadora:

Profa. Dra. Helenice de Souza Spinosa 
Dedico esta tese

aos meus queridos pais Tamotu e Dagmar pelo amor, incentivo e apoio

ao meu irmão Márcio pelo apoio

à minha amada filha Bianca pela alegria que me traz 
à querida orientadora Helenice pela oportunidade, carinho, apoio e compreensão 


\section{AGRADECIMENTOS}

- Às Profas. Dras. Maria Martha Bernardi e Silvana Lima Górniak pelo auxílio e sugestões pertinentes à tese.

- Às Profas. Dras. Ana Cristina Tasaka, Rosane e Mitsui Haragushi, pela ajuda na coleta da planta e em outros momentos da tese.

- Ao colega e amigo Paulo César Maiorka pelo auxílio no estudo anatomopatológico.

- À estagiária Milena pelo auxílio nos experimentos.

- À Inês Cordeiro do Instituto de Botânica do Estado de São Paulo pela identificação da planta.

- À todos os animais utilizados durante a tese que cederam suas vidas em prol deste estudo.

- À todos os funcionários do Biotério pela dedicação e carinho aos animais experimentais.

- À todos os colegas da pós-graduação pela agradável convivência.

- Aos meus queridos amigos que trouxeram apoio e carinho nos momentos difíceis e também pelas alegrias que dividimos juntos.

- À Capes e ao CNPq pelo auxílio financeiro à tese.

- Ao curso de pós-graduação em Patologia Experimental e Comparada da FMVZ-USP pela oportunidade de desenvolver este trabalho.

Este trabalho foi realizado no Laboratório de Farmacologia e Toxicologia do departamento de Patologia da FMVZ-USP 


\section{LISTA DE ILUSTRAÇÕES}

\section{FIGURAS}

Pág.

Figura 1. Solanum lycocarpum.

Figura 2. Peso de ratos que receberam, por 36 dias, $3 \%$ de Solanum lycocarpum na ração ou apenas ração moída (controle). São apresentadas as médias e os respectivos erros padrões.

Figura 3. Consumo médio de ração e de água de ratas que receberam 3\% de Solanum lycocarpum $(n=15)$ na ração ou apenas ração moída (controle: $\mathrm{n}=15$ ). São apresentadas as médias e os respectivos erros padrões. ${ }^{*} \mathrm{p}<0,05$, teste t.

Figura 4. A)Ovário animal controle (HE 4X) B) Ovário, de uma rata que recebeu S. lycocarpum a $3 \%$ na ração, com pequeno cisto folicular repleto de substância eosinofílica semelhante a colóide (seta) (HE 4X). C) Parede do cisto folicular (seta), repleto de substância eosinofílica semelhande a colóide $\left({ }^{*}\right)(H E 4 X)$. D) Cisto folicular com grande quantidade de células na parede interna do cisto (seta) (HE 4X).

Figura 5. A) Grande cisto folicular com interior repleto de material necrótico $\left.{ }^{*}\right)$. Parede interna de evestimento formada por células foliculares (seta) (4X). B) Revestimento endometrial em oviduto em femea controle (HE 4X). C) Hiperplasia de endométrio (seta) em oviduto de animal tratado durante 37 dias com a Solanum lycocarpum a 3\% na ração (HE 4X).

Figura 6. A) Fígado animal controle (HE 4X). B) Fígado apresentando proliferação de ductos biliares (seta) (HE 4X). C) Congestão hepática (seta) (HE 4X).

Figura 7. A) Rim animal controle (HE 4X). B) Congestão renal (seta) (HE $4 X)$.

Figura 8. Peso de ratos que receberam, por 60 dias, 3\% de Solanum lycocarpum na ração ou apenas ração moída (controle). São apresentadas as médias e os respectivos erros padrões.

${ }^{*} \mathrm{p}<0,05$, test $\mathrm{t}$.

Figura 9. Consumo médio de ração e de água de ratos que receberam $3 \%$ de Solanum lycocarpum $(n=9)$ na ração ou apenas ração moída (controle: $\mathrm{n}=10$ ). São apresentadas as médias e os respectivos erros padrões. ${ }^{*} p<0,05$, teste t.

Figura 10. Consumo de ração (em gramas) de ratas que receberam 
durante o período de pré-implantação (dia 1 ao 6) ou de organogênese (dia 6 ao 16) 3\% de Solanum lycocarpum na ração ou apenas ração moída (controle). São apresentadas as médias e os respectivos erros padrões. ${ }^{*} \mathrm{p}<0,05$, ANOVA seguida de Tukey-Kramer.

Figura 11. Consumo de água (em mililitros) de ratas que receberam durante o período de pré-implantação (dia 1 ao 6) ou de organogênese (dia 6 ao 16) 3\% de Solanum lycocarpum na ração ou apenas ração moída (controle). São apresentadas as médias e os respectivos erros padrões.

* $p<0,05$, ANOVA seguida de Tukey-Kramer.

\section{TABELAS}

Tabela 1. Peso e ganho de peso (em gramas) de ratas que receberam, por 36 dias, $3 \%$ de Solanum lycocarpum na ração ou apenas ração moída (controle). São apresentadas as médias e os respectivos erros padrões.

Tabela 2. Consumo médio de ração (em g) e de água (em $\mathrm{ml}$ ) de ratas que receberam, por 36 dias, 3\% de Solanum lycocarpum na ração ou apenas ração moída (controle). São apresentadas as médias e os respectivos erros padrões.

Tabela 3. Intervalo entre ciclos e número de dias em cada fase do ciclo estral, avaliado durante 20 dias, em ratas que receberam do $17^{\circ}$ ao $37^{\circ}$ dia, 3\% de Solanum lycocarpum na ração ou apenas ração moída (controle). São apresentadas as médias e os respectivos erros padrões.

Tabela 4. Peso dos órgãos de ratas que receberam, por no mínimo 37 dias, $3 \%$ de Solanum lycocarpum na ração ou apenas ração moída (controle). São apresentadas as médias e os respectivos erros padrões.

Tabela 5. Valores de alanina amimotransferase (ALT), aspartato aminotransferase (AST), albumina, creatinina, fosfatase alcalina e proteínas totais de ratas que receberam, por no mínimo 37 dias, 3\% de Solanum lycocarpum na ração ou apenas ração moída (controle). São apresentadas as médias e os respectivos erros padrões.

Tabela 6. Peso e ganho de peso (em gramas) de ratos que receberam, por 60 dias, 3\% de Solanum lycocarpum na ração ou apenas ração moída (controle). São apresentadas as médias e os respectivos erros padrões.

Tabela 7. Consumo médio de ração (em g) e de água (em $\mathrm{ml}$ ) por rato que recebeu, por 60 dias, $3 \%$ de Solanum lycocarpum na ração ou apenas ração moída (controle). São apresentadas as média e os respectivos erros padrões.

Tabela 8. Peso (em gramas) dos órgãos de ratos que receberam, por 60 
dias, 3\% de Solanum lycocarpum na ração ou apenas ração moída (controle). São apresentadas as médias e os respectivos erros padrões.

Tabela 9. Valores de ALT, AST, albumina, creatinina, fosfatase alcalina e proteínas totais de ratos que receberam, por 60 dias, 3\% de Solanum lycocarpum na ração ou apenas ração moída (controle). São apresentadas as médias e os respectivos erros padrões.

Tabela 10. Consumo de ração (em gramas) de ratas que receberam durante o período de pré-implantação (dia 1 ao 6) ou de organogênese (dia 6 ao 16) 3\% de Solanum lycocarpum na ração ou apenas ração moída (controle). São apresentadas as médias e os respectivos erros padrões.

Tabela 11. Consumo de água (em $\mathrm{ml}$ ) de ratas que receberam durante 0 período de pré-implantação (dia 1 ao 6) ou de organogênese (dia 6 ao 16) $3 \%$ de Solanum lycocarpum na ração ou apenas ração moída (controle). São apresentadas as médias e os respectivos erros padrões.

Tabela 12. Desempenho reprodutivo de ratas que receberam durante 0 período de pré-implantação (dia 0 ao 5) ou de organogênese (dia 6 ao 15) $3 \%$ de Solanum lycocarpum na ração ou apenas ração moída (controle).

Tabela 13. Exame visceral de fetos cujas ratas receberam durante o 59-60 período de pré-implantação (dia 0 ao 5) ou de organogênese (dia 6 ao 15) $3 \%$ de Solanum lycocarpum na ração ou apenas ração moída (controle).

Tabela 14. Exame esquelético de fetos cujas ratas receberam durante o período de pré-implantação (dia 0 ao 5) ou de organogênese (dia 6 ao 15) $3 \%$ de Solanum lycocarpum na ração ou apenas ração moída (controle). 


\section{RESUMO}

Maruo, V. M. Estudo dos possíveis efeitos tóxicos da exposição à Solanum lycocarpum em ratos adultos e em sua prole. [Study of the possible toxic effects of Solanum lycocarpum exposure in adult rats and their offspring]. 2002. f. Tese (Doutorado em Patologia Experimental e Comparada) - Faculdade de Medicina Veterinária e Zootecnia, Universidade de São Paulo, São Paulo.

Solanum lycocarpum St. Hill é uma planta comum no cerrado brasileiro e possui um alcalóide com configuração estereoespecífica para a síntese de hormônios esteróides. O presente estudo foi desenvolvido para determinar os possíveis efeitos tóxicos da ingestão dos frutos de $S$. lycocarpum (3\% adicionados à dieta) em ratos adultos machos (60 dias de administração), fêmeas (37 dias) e fêmeas prenhes (nos períodos de pré-implantação e organogênese). Poucas diferenças significantes no peso corpóreo e no consumo de água e ração foram observadas. Nenhuma diferença significante foi detectada no ganho de peso dos animais e no ciclo estral. Ratas tratadas apresentaram redução significante nos pesos do útero e do fígado. Porém, nenhuma diferença significante foi observada nos pesos de outros órgãos (adrenal, fígado, vesícula seminal, testículo e ovário) e na avaliação de enzimas e proteínas sangüíneas de ratos fêmeas e machos. Ao estudo anatomopatológico as fêmeas apresentaram maior incidência de hiperplasia do epitélio endometrial, cistos foliculares, proliferação de ductos biliares, congestão hepática e renal. A administração da planta no período de pré-implantação causou poucas alterações nos consumos de água e comida das fêmeas e sua prole apresentou aumento de hemorragia do bulbo olfatório. O consumo da planta durante a organogênese aumentou a média de filhotes fêmeas, reduziu o peso da placenta e aumentou o número de fetos com esternébrios assimétricos. Tomando estes dados em conjunto, pode-se sugerir que a administração da S. lycocarpum à $3 \%$ na ração causa efeitos tóxicos em ratas adultas e na prole, principalmente quando exposta durante o período de organogênese.

Unitermos: planta, toxicologia, ratos. 


\section{SUMMARY}

Maruo, V. M. Study of the possible toxic effects of Solanum lycocarpum exposure in adult rats and their offspring. [Estudo dos possíveis efeitos tóxicos da exposição à Solanum lycocarpum em ratos adultos e em sua prole]. 2002. f. Tese (Doutorado em Patologia Experimental e Comparada) - Faculdade de Medicina Veterinária e Zootecnia, Universidade de São Paulo, São Paulo.

Solanum lycocarpum St. Hill is a common plant in Brazilian savanna. This plant has an alkaloid with stereospecific configuration to the synthesis of steroid hormones. Since the plant may be long-term consumed, the present study was undertaken to determine the possible toxic effects of $S$. lycocarpum fruit ingestion (3\% added to the diet) on male (60 days of administration), female (37 days) adult rats and pregnant female (during preimplantation and organogenesis). Few significant differences in the body weight and consumption of food and water were observed. No significant differences were detected in the male and female weight gain and the estrous cycle. Female treated rats showed a significant reduction in the uterus and liver weights. However, no significant differences were observed in other organ (adrenal, liver, seminal vesicle, testicle and ovary) weights and in the evaluation of blood enzimes and proteins of the female and male rats. The anatomopathological study showed a higher incidence of endometrial epithely hiperplasy, pholicular cysts, biliary ducts proliferation, hepatic and renal congestion in female rats. Plant administration during preimplantation caused few alterations in food and water consumption in female and their offspring showed increase in olfactory bulb hemorragy. Plant consumption during organogenesis increased the media of female pups, reduced placental weight and increased the number of fetuses with assimetric sternebrae. These data suggest that the S. lycocarpum administration at $3 \%$ causes toxic effects in adult female rats and in the offspring, specially when exposed to the plant during organogenesis. 
SUMÁRIO

\section{Pág.}

1 INTRODUÇÃO 12

2 OBJETIVOS 20

3 MATERIAIS E MÉTODOS 21

$\begin{array}{lll}3.1 & \text { Animais } & 21\end{array}$

3.2 Administração de S. lycocarpum 21

$\begin{array}{lll}3.3 & \text { Procedimento } & 22\end{array}$

3.3.1 Controle do ciclo estral 22

3.3.2 Dosagem dos níveis séricos de enzimas e proteínas 22

3.3.3 Avaliação do aparelho reprodutor de machos e fêmeas 23

3.3.4 Estudo anatomopatológico 23

$\begin{array}{ll}\text { 3.3.5 Acasalamento } & 23\end{array}$

3.3.6 Laparotomia e avaliação do desempenho reprodutivo materno aos 21 $\begin{array}{ll}\text { dias de gestação. } & 24\end{array}$

3.3.7 Análise dos fetos ao $21^{0}$ dia de gestação 25

$\begin{array}{ll}\text { 3.3.8 Análise estatística } & 26\end{array}$

4 DELINEAMENTO EXPERIMENTAL E RESULTADOS 27

4.1 Experimento 1. Efeitos do consumo de S. lycocarpum em ratas $\begin{array}{ll}\text { adultas. } & 27\end{array}$

4.2 Experimento 2. Efeitos do consumo de S. lycocarpum em ratos 41 adultos. 
4.3 Experimento 3. Efeitos do consumo de S. lycocarpum durante a gestação.

5 DISCUSSÃO

6 CONCLUSÕES

7 REFERÊNCIAS 


\section{INTRODUÇÃO}

A Solanum lycocarpum St. Hil (do grego "lycos" = lobo e "karpos" = fruto, pois os frutos são apreciados pelo lobo-guará, Chrysocyon brachyurus - KISSMANN e DORIS, 1995) (Fig. 1) é uma planta nativa no Brasil, da família Solanaceae, conhecida vulgarmente por fruta-do-lobo, lobeira, capoeira-branca, beringela, jurubebão, baba-de-boi, jurubeba de boi, entre outras denominações. Esta planta costuma ser confundida com a Solanum grandiflorum Ruiz et Pav., que possui flores maiores e frutos menores, além das características apresentadas por suas quatro variedades (para detalhes, ver KISSMANN e DORIS, 1995)

A S. lycocarpum tem ampla distribuição geográfica, sendo encontrada nos estados de Minas Gerais, Rio de Janeiro, São Paulo, Paraná, Goiás, Mato Grosso, Mato Grosso do Sul, Tocantins, Amazonas e Pará (LORENZI, 1991; KISSMANN e DORIS, 1995). É uma planta perene, arbustiva ou arbórea, medindo de 2,0 a 3,5 metros de altura, com ramos tortuosos e formações espinhosas. Suas folhas são pecioladas, alternadas, sinuosas, com acúleos amarelo-avermelhados e levemente curvos na nervura mediana central, as flores são violáceas de corola rotada, dispostas laterais e subterminais. Produz frutos, bagas globosas de 8 a 15 centímetros de diâmetro. A reprodução é realizada pelas sementes, que são numerosas, achatadas e reniformes (SCAVONE e PANIZZA, 1981; LORENZI, 1991; KISSMANN e DORIS, 1995). 


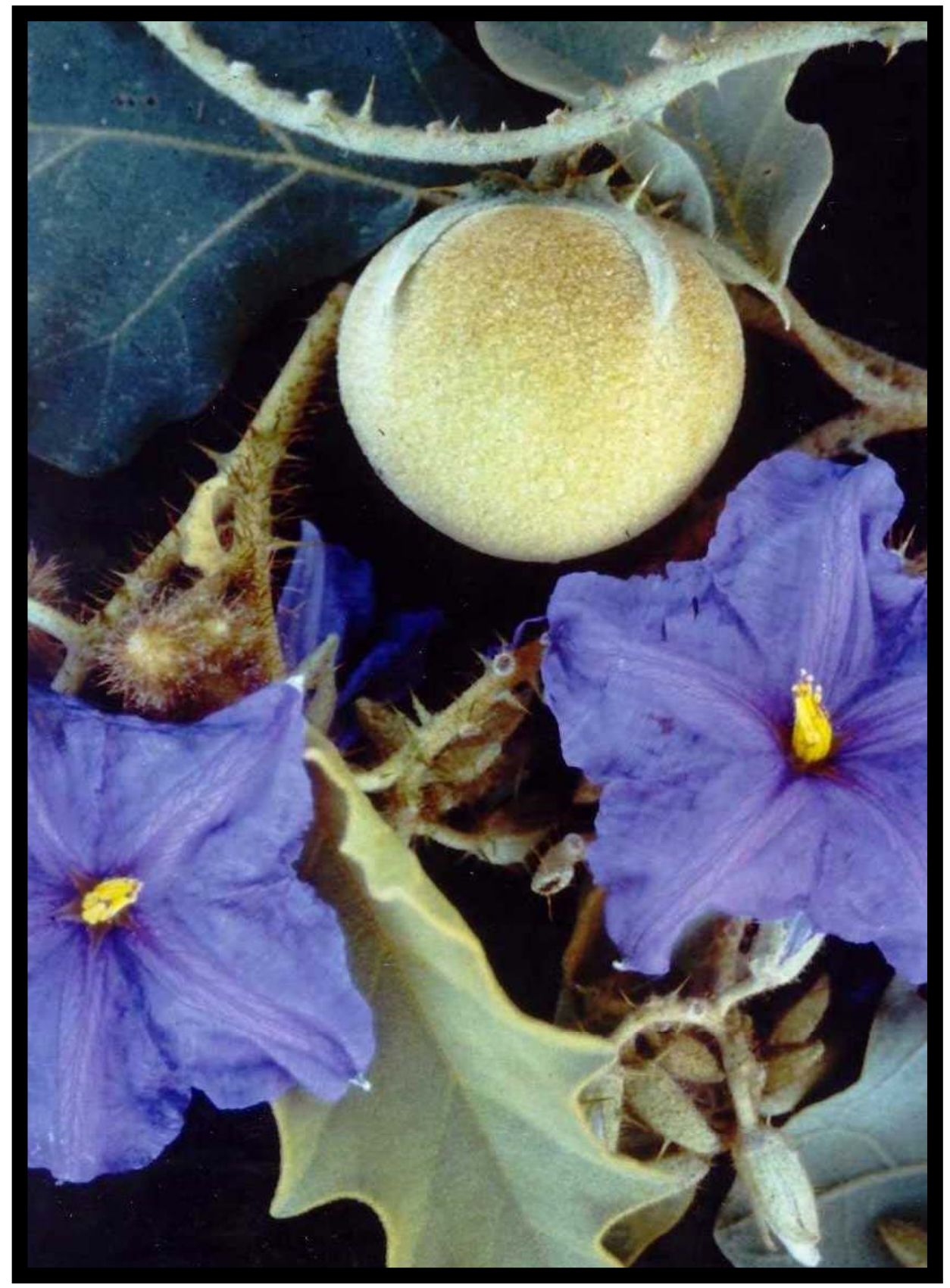

Figura 1. Solanum lycocarpum. 
S. lycocarpum é muito freqüente em pastagens ocorrendo também em beira de estradas e terrenos baldios, tendo preferência por solos arenosos. Floresce mais intensamente durante os meses de maio a julho. Os frutos são comestíveis, sendo usado no preparo de doces, que tem sabor e aspecto semelhante à goiabada (CRUZ, 1985).

Em medicina popular, atribui-se a esta planta propriedades terapêuticas (CRUZ, 1985; LORENZI, 1991; DALL'AGNOL e VON POSER, 2000). As folhas são recomendadas para o tratamento da epilepsia, espasmos, dor renal e abdominal. As flores são empregadas para o tratamento de hemorróidas e a preparação de um xarope caseiro para resfriados e como expectorante. As raízes são usadas na hepatite. Os frutos são empregados para o controle da diabetes e obesidade e, topicamente, assados e quentes teriam efeito benéfico quando colocado sobre partes atrofiadas restaurando o estado normal do tecido, além de ser usado para mordedura de cobras. Uma preparação medicinal feita com os frutos verdes em solução aquosa que é filtrada e seca obtendo-se o polvilho-de-lobeira, é comercializada em cápsulas como fitoterápico no Brasil e em outros países, sendo recomendada para o controle da diabetes, obesidade e para baixar os níveis de colesterol (DALL'AGNOL e VON POSER, 2000).

A família Solanaceae, além do gênero Solanum (do qual faz parte também a batata, berinjela, jiló), possui outros 84 gêneros com mais de mil espécies, sendo que dentre estes gêneros destacam-se plantas utilizadas na alimentação (como o tomate, pimentão, pimenta vermelha), cultivadas como ornamentais, em virtude de suas flores (trepadeiras de Solanum com flores 
roxas e frutos vermelhos, Cestrum, Petunia) e plantas que podem ser tóxicas, como, por exemplo, Atropa da qual se extrai a atropina. Em particular, várias espécies do gênero Solanum, inclusive a batata (S. tuberosum L.) podem ser tóxicas. Os efeitos tóxicos parecem ser, em parte, resultado da ação de alcalóides esteroídicos, como a solanina e a solanidina. Estes alcalóides, em sua forma natural, não são bem absorvidos, porém após a ingestão sofrem hidrólise no trato gastrointestinal, dando origem a "alcaminas" que são absorvidas e produzem efeitos tóxicos (NISHIE et al., 1971; BRUNETON, 2001).

Os sinais de toxicidade por glicoalcalóides em animais e humanos incluem cólicas no abdômen e no estômago, gastroenterites, diarréia, vômitos, sensação de queimação nos lábios e na boca, pele quente, febre, pulso rápido e cefaléia (VAN GELDER, 1990). A toxicidade destes glicoalcalóides pode ser causada por efeitos adversos, tais como: indução da ornitina descarboxilase hepática, uma enzima marcadora da proliferação celular (CALDWELL et al., 1991); rompimento das membranas celulares afetando o sistema digestivo (BLANKEMEYER et al., 1992 e 1995; RODDICK et al., 1992) e efeitos anticolinesterásicos no Sistema Nervoso Central (RODDICK, 1989). Há inclusive trabalhos mostrando que a solanina possui efeito inibidor da colinesterase in vitro (ORGELL, 1963; HAYES; CAMPBELL, 1986; BRUNETON, 2001). Estudos recentes utilizando solamargina purificada da planta chinesa S. incanum dão conta de que esta substância é citotóxica provavelmente por aumentar a expressão gênica de 
receptores TNF tipo I, que tem sido envolvidos na apoptose (morte celular programada) (HSU et al., 1996).

Há vários relatos a respeito de intoxicações provocadas pela presença de glicoalcalóides como a solanina em batatas (principalmente nas partes aéreas, tubérculos verdes, germinados ou apodrecidos), causando no homem e em animais sintomatologia que envolve distúrbios gastrointestinais (necrose gástrica e intestinal), desordens de natureza neurológica como esturpor, depressão do Sistema Nervoso Central e morte por parada respiratória (NISHIE et al.; 1971, MATOS, 1989; BRUNETON, 2001).

Uma manifestação dos efeitos adversos produzidos por alcalóides pode ser a teratogenicidade (KEELER et al., 1991; RENWICK et al., 1984). O interesse pelos estudos envolvendo toxicologia reprodutiva e os alcalóides presentes na batata se iniciaram quando RENWICK, em 1972, observou uma correlação estatisticamente significante entre o consumo de batatas em regiões específicas do Reino Unido, Irlanda e América do Norte e a incidência de anencefalia e spina bifida.

Vários outros estudos envolvendo a administração de plantas de gênero Solanum e seus glicoalcalóides também demonstraram o aparecimento de teratogenicidade. Assim, a administração por gavage de S. dulcamara, S. eleaeagnifolium e S. tuberosum em hamsters fêmeas induziram malformações congênitas como exencefalia e encefalocele em fetos, causando também necrose do trato gastrointestinal (KEELER et al., 1990). A administração de solanina e solasodina em embriões de truta arcoíris e medaka, duas espécies de peixes, levou a um aumento da mortalidade 
embrionária (CRAWFORD e KOCAN, 1993); em outro estudo com embriões de galinha a solanina também demonstrou efeito teratogênico, produzindo alterações de tronco e pelve (NISHIE et al., 1971).

Assim como outras plantas do gênero Solanum, a $S$. lycocarpum também possui glicoalcalóides esteroidais, que foram caracterizados como sendo a solamargina e a solasonina, cuja aglicona corresponde ao composto solasodina (MOTIDOME et al., 1970), e de onde um 33-acetoxipregno-5,16dien-20-ona é obtido (HARAGUCHI et al., 1978), assim como um alcalóide com configuração estereospecífica para a síntese de hormônios esteróides (KERBER et al., 1993).

Há alguns estudos mostrando os efeitos da S. lycocarpum na reprodução, porém empregando-se uma solução aquosa do polvilho do fruto. Assim, SÁ et al. (2000), administrando a suspensão aquosa do polvilho por 5 dias a ratos e camundongos, não observaram nenhuma alteração no peso dos órgãos sexuais e na concentração de esperma dos machos tratados, exceto redução do peso da próstada de camundongos; estes autores concluíram que neste protocolo empregado, a planta não produziu toxicidade no sistema reprodutor dos machos. PETERS et al. (1997 e 2001) relataram que a suspensão aquosa do polvilho-de-lobeira administrado, por gavage, durante $01^{\underline{0}}$ ao $4^{\underline{0}}$ dia de gestação (período de implantação) da rata não interfere com a transporte do zigoto e no desenvolvimento do blastocisto; não observaram também nenhuma alteração nos índices de implantação e de reabsorção, no número de fetos vivos, nos pesos das placentas e dos fetos das ratas tratadas, indicando ausência de efeitos desta preparação da 
planta sobre o período de implantação. GUERRA et al. (1997), administrando a solução aquosa do polvilho-de-lobeira durante o período de organogênese da rata, não observaram alterações no peso corporal das mães durante a gestação, no peso das placentas, pulmão, rim, cérebro e fígado da prole feminina; na prole masculina observou-se redução do peso corpóreo e do fígado e aumento do peso da placenta. Estes autores concluíram que a administração da solução aquosa do polvilho-de-lobeira durante o período de organogênese, afetou o desenvolvimento de fetos do sexo masculino.

Estes trabalhos acima citados empregaram o polvilho-de-lobeira, uma preparação de uso humano como fitoterápico, visando aprofundar os conhecimentos dos efeitos desta planta em medicina humana, avaliando-se o seu potencial tóxico sobre a reprodução de mamíferos.

Por outro lado, ainda não existem trabalhos na literatura investigando o potencial tóxico dos frutos da $S$. lycocarpum, planta está presente freqüentemente em pastagens, podendo ser ingerida pelos animais em idade fértil e em condições naturais e que por ser do gênero Solanum e possuir glicoalcalóides esteroidais poderia causar efeitos tóxicos agudos, crônicos e sobre a reprodução principalmente em animais de produção (bovinos, ovinos, caprinos, etc.) reduzindo os índices de produtividade dos rebanhos brasileiros.

Recentemente, em nossos laboratório, alguns experimentos foram realizados, empregando-se os frutos da S. lycocarpum administrados a $10 \%$ na ração de ratos, observou-se que a administração do $5^{0}$ ao $15^{0}$ dia de 
gestação apresentou uma tendência em prejudicar o desempenho reprodutivo de ratas, diminuindo o número de fêmeas paridas em $50 \%$. Porém, não se pode concluir que este prejuízo foi causado apenas pela planta ou seus príncipios ativos, pois também foi observada uma redução de quase $50 \%$ no ganho de peso durante a gestação (dados não publicados), indicando toxicidade materna.

Embora os dados aqui expostos mostrem que os glicoalcalóides esteroidais presentes em algumas plantas, particularmente do gênero Solanum, podem desencadear vários efeitos tóxicos, estes achados ainda não foram demonstrados para a S. lycocarpum, planta de ampla distribuição geográfica, facilmente encontrada nas pastagens e que pode ser ingerida em condições naturais por animais adultos. Desta forma, no presente trabalho estudou-se os possíveis efeitos tóxicos da S. lycocarpum em ratos, machos e fêmeas adultos, e quando administrada em ratas prenhes. 


\section{OBJETIVOS}

Estudar os possíveis efeitos tóxicos produzidos pelo consumo de $S$. lycocarpum em ratos machos e fêmeas adultos e quando administrada a ratas prenhes.

\section{Objetivos específicos:}

- Avaliar os possíveis efeitos tóxicos da S. lycocarpum quando administrada por, no mínimo, 37 dias em ratas fêmeas;

- Avaliar os possíveis efeitos tóxicos da S. lycocarpum quando administrada durante 60 dias em ratos machos;

- Avaliar a toxicidade materna e o desempenho reprodutivo de ratas que receberam S. lycocarpum durante o período de pré-implantação e de organogênese;

- Avaliar os possíveis efeitos tóxicos na prole exposta a S. lycocarpum durante o período de pré-implantação e de organogênese. 


\section{MATERIAIS E MÉTODOS}

\subsection{Animais}

Foram utilizados ratos (machos e fêmeas adultos) Wistar de mesma linhagem, obtidos em nossos biotérios através de cruzamentos sucessivos. Os animais foram alojados, sozinhos ou em grupos de quatro ou cinco, em gaiolas plásticas com tampas metálicas, medindo $40 \times 50 \times 20 \mathrm{~cm}$. Todas as gaiolas foram mantidas em sala com temperatura controlada por meio de aparelhos de ar condicionado $\left(20 \pm 3^{\circ} \mathrm{C}\right)$ e com ciclo de doze horas de claro e escuro, sendo a luz acesa às 6:00 horas.

Água e comida foram fornecidas ad libitum aos animais durante todo o procedimento experimental.

\subsection{Administração de S. lycocarpum}

A S. lycocarpum foi coletada na região de Caxambu, Minas Gerais e identificada por Inês Cordeiro do Instituto de Botânica do Estado de São Paulo. Foram utilizados os frutos verdes da planta, os quais foram picados e colocados em forno de microondas, em potência alta, para secagem do material. A seguir, os frutos foram moídos (moinho Tecnal - modelo 11 340) e devidamente acondicionados em invólucros de papel, isentos da ação de umidade e luminosidade.

A planta foi adicionada à ração moída, na proporção de 3\%, sendo oferecida durante 60 dias para machos e para fêmeas por, pelo menos 37 dias (para estudar os efeitos sobre o ciclo estral) ou, ainda, do $1^{0}$ ao $6^{\underline{0}}$ dia 
de gestação (período de pré-implantação) e a partir do $6^{0}$ até 0 16ํํำ dia de gestação (período de organogênese em ratos).

\subsection{Procedimento}

\subsubsection{Controle do ciclo estral}

O ciclo estral foi acompanhado fazendo-se observações microscópicas diárias do lavado vaginal. Os lavados foram realizados sempre pela manhã, sendo obtidos pela introdução e aspiração de solução de $\mathrm{NaCl}$ 0,9\% $(0,5 \mathrm{ml})$ na vagina, com o auxílio de uma pipeta automática com ponteiras plásticas descartáveis. O lavado obtido foi colocado em lâminas de vidro para observação em microscópio óptico. Foi considerado indicativo da fase de diestro a existência de grande quantidade de leucócitos, com ou sem a presença de muco, no material examinado; o proestro foi indicado pelo achado de muitas células epiteliais nucleadas; a presença de muitas células queratinizadas indicou a fase de estro; e, finalmente, a predominância de células queratinizadas e de leucócitos no esfregaço, foi tomada como indicativo do metaestro.

\subsubsection{Dosagem dos níveis séricos de enzimas e proteínas}

Ao final dos experimentos, após a anestesia dos animais por inalação de éter etílico, amostras de sangue foram colhidas da veia cava de cada rato em seringas heparinizadas (Liquemine - marca registrada da Roche, Rio de Janeiro, Brasil). O sangue foi centrifugado para a obtenção do soro, sendo as amostras mantidas $\mathrm{a}-10^{\circ} \mathrm{C}$ até a análise. 
Alanina aminotransferase (ALT), aspartato aminotransferase (AST), albumina, creatinina, fosfatase alcalina e proteínas totais foram determinadas usando kits comerciais (Laborlab, Guarulhos, Brasil).

\subsubsection{Avaliação do aparelho reprodutor de machos e fêmeas}

Os animais foram pesados e submetidos a eutanásia em cuba de vidro contendo éter etílico. O aparelho reprodutor do macho foi retirado fazendo-se uma incisão na região ventro-púbica e separando-se os testículos e a vesícula seminal, que foram pesados separadamente e destinados para exame anatomopatológico. Em fêmeas foram retirados e pesados os ovários e útero para exame anatomopatológico.

\subsubsection{Estudo anatomopatológico}

Os animais foram submetidos a eutanásia através de inalação de éter etílico e procedeu-se a necrópsia, sendo retirados adrenais, pulmões, rins, estômago, intestinos e fígado. Adrenais e fígado foram também pesados. Após inspeção macroscópica, os tecidos foram fixados, cortados e corados com hematoxilina-eosina $(\mathrm{HE})$, sendo observadas possíveis lesões em microscopia óptica.

\subsubsection{Acasalamento}

Quando a fêmea estava no estro (ou seja, na fase mais propícia para o acasalamento), um macho comprovadamente fértil foi colocado na mesma gaiola desta fêmea, durante o período escuro do ciclo de luz. Na manhã do 
dia seguinte, foi feito o lavado vaginal. A prenhez foi confirmada pela presença de espermatozóides neste lavado e foi indicativo do primeiro dia de prenhez.

Durante o período de gestação foi mantida uma fêmea por gaiola e foram avaliados os consumos de água e ração e o ganho de peso das fêmeas.

\subsubsection{Laparotomia e avaliação do desempenho reprodutivo materno aos}

\section{1 dias de gestação.}

No $21^{0}$ dia de gestação, após a eutanásia dos animais por inalação de éter etílico, foi realizada uma laparotomia. Inicialmente fez-se o exame macroscópico para verificar o aparecimento de lesão ou patologia em órgãos. A seguir, os cornos uterinos foram expostos e foi feita a contagem dos sítios de implantação e pesagem do útero gravídico.

Os fetos foram examinados macroscopicamente quanto a anomalias externas, quantificados quanto ao sexo, pesados individualmente, assim como suas respectivas placentas.

Foram examinados os seguintes parâmetros: conformação craniana, implantação das orelhas, pálato, conformação da cauda e das patas e perfuração anal.

Os ovários foram retirados, observados e os corpos lúteos contados, com o auxílio de uma lupa, para avaliação da quantidade de óvulos eliminados. 
A porcentagem de perda embrionária pré-implantação foi determinada através da seguinte proporção:

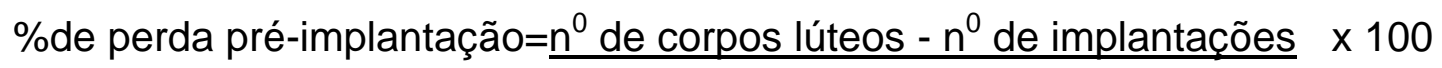
nº de corpos lúteos

Para a determinação da perda embrionária após implantação foi utilizada a proporção:

$\%$ de perda pós-implantação $=\underline{n^{0} \text { de implantações }-n^{0} \text { de fetos vivos }} \times 100$ $\mathrm{n} \stackrel{0}{-}$ de implantações

\subsubsection{Análise dos fetos ao $21^{0} \stackrel{0}{ }$ dia de gestação}

Após a retirada do útero, os fetos foram submetidos a um minucioso exame externo para a pesquisa de possíveis malformações e/ou anomalias e subdivididos em dois grupos diferentes. Metade dos fetos foi eviscerada e, após diafanização e coloração com alizarina, examinada quanto a presença de alterações esqueléticas, segundo método de coloração proposto por STAPLES e SCHENELL (1964). Procedeu-se a avaliação esquelética individual dos fetos, com auxílio de lupa, das seguintes estruturas ósseas: crânio, esterno, vértebras, costelas, metacarpos, matatarsos, falanges anteriores, coluna vertebral e demais ossos. Os pontos de ossificação, que determinam o grau de desenvolvimento fetal, foram examinados, segundo método proposto por ALIVERTI et al. (1979). A outra metade dos fetos, após fixação completa em Bowin e descalcificação óssea, foi submetida a análise de malformações e/ou anomalias internas segundo método de secções 
seriadas de WILSON (1965). As fatias obtidas foram colocadas em recipiente obedecendo a seqüência dos cortes e observadas, com auxílio de lupa, as seguintes estruturas: boca, nariz, olhos, cérebro, coração, rins, bexiga, gônadas, pulmões, traquéia, timo, glândulas salivares, esôfago, diafragma, intestinos e fígado.

\subsubsection{Análise estatística}

Foi empregado o software GRAPHPAD INSTAT (1993) para a realização das seguintes análises estatísticas:

- análise de variância ANOVA para dados paramétricos, seguida do teste de Dunnett para comparação entre três médias.

- Análise de Kruskal-Wallis para dados não paramétricos para comparação entre os dados de três grupos.

- $\quad$ Teste t de Student para a comparação entre duas médias.

Empregou-se também o teste de Qui-quadrado para comparar a presença ou ausência de malformações e/ou anomalias dos fetos dos grupos experimentais e controle (DORIA FILHO, 1999).

O nível de significância crítico para todas as análises estatísticas realizadas foi de $p<0,05(5 \%)$. 


\section{DELINEAMENTO EXPERIMENTAL E RESULTADOS}

\subsection{Experimento 1. Efeitos do consumo de S. lycocarpum em ratas adultas.}

Foram utilizadas 30 fêmeas com 90 dias de idade, as quais foram divididas em 2 grupos iguais: um controle e um experimental. Os animais do grupo experimental receberam $3 \%$ de S. lycocarpum adicionada à ração moída, por pelo menos 37 dias, enquanto os animais do grupo controle receberam ração moída durante o mesmo período de tempo, conforme descrito no item 3.2. Os animais foram pesados a cada 2-3 dias e o ganho de peso avaliado entre o $1^{\circ}$ e $36^{\circ}$ dia de tratamento. $O$ consumo médio de ração e água por gaiola foi avaliado diariamente, durante 36 dias de tratamento.

O ciclo estral foi avaliado, diariamente, do $17^{0}$ até $037^{0}$ dia de tratamento. A partir de então, quando as fêmeas estavam em diestro foram submetidas à anestesia por inalação de éter, sendo coletado o sangue para determinação dos níveis séricos de enzimas e proteínas, conforme descrito no item 3.3.2. Foi feita também a retirada de órgãos (útero, ovários, adrenais, fígado, pulmões, rins, estômago e intestino) para a pesagem e realização do exame anatomopatológico, conforme itens 3.3.3. e 3.3.4.

A Tab. 1 e a Fig. 2 mostram o peso e ganho de peso de ratas que receberam 3\% de S. lycocarpum na ração. Assim, nota-se redução do peso nos dias $5,10,12,15,17,26,29,31$ e 33 de tratamento nos animais que receberam a planta, quando comparado com aqueles do grupo controle; não 
foi observada diferença significante no ganho de peso entre os animais dos grupos controle e experimental.

A Tab. 2 e a Fig. 3 mostram o consumo médio de ração e de água de ratas que receberam $3 \%$ de $S$. lycocarpum na ração. Assim, nota-se aumento do consumo médio de ração apenas no $25^{\circ}$ dia de tratamento nos animais que receberam a planta, quando comparado com aqueles do grupo controle. Quanto ao consumo de água, nota-se redução do consumo médio de água nos dias $2,3,4,12,17,20,23,31$ e 33 de tratamento nos animais que receberam a planta, quando comparado com aqueles do grupo controle.

A Tab. 3 mostra a avaliação do ciclo estral (170 ao $37^{\circ}$ dia de tratamento) de ratas que receberam 3\% de S. lycocarpum na ração. Assim, nota-se que a administração da planta não produziu nenhuma alteração significante no número de dias de cada fase do ciclo estral, nem interferiu com o intervalo entre ciclos, quando comparado com os animais do grupo controle.

A Tab. 4 mostra o peso de diferentes órgãos de ratas que receberam $3 \%$ de S. lycocarpum na ração. Assim, nota-se que a administração da planta promoveu redução nos pesos do útero e do fígado destas fêmeas, porém nenhuma diferença significante foi observada nos pesos dos demais órgãos.

A Tab. 5 mostra os efeitos do tratamento com 3\% de S. lycocarpum adicionada à dieta, em parâmetros séricos das ratas. Assim, nota-se que não houve diferenças significantes entre os animais dos dois grupos nos 
valores de ALT, AST, albumina, creatinina, fosfatase alcalina e proteínas totais.

Ao exame macroscópico de vísceras, em uma das fêmeas do grupo experimental foi detectada a presença de cistos ovarianos. Os achados anatomopatológicos revelaram, nas fêmeas do grupo experimental, maior freqüência de hiperplasia do epitélio endometrial e cistos foliculares (Figs. 4 e 5), congestão hepática e proliferação de ductos biliares (Fig. 6) e congestão renal (Fig. 7). 
Tabela 1. Peso e ganho de peso (em gramas) de ratas que receberam, por 36 dias, 3\% de Solanum lycocarpum na ração ou apenas ração moída (controle). São apresentadas as médias e os respectivos erros padrões.

\begin{tabular}{ccc}
\hline Dia & Controle $(\mathrm{n}=15)$ & S. lycocarpum $(\mathrm{n}=15)$ \\
\hline 1 & $236,40 \pm 8,34$ & $218,53 \pm 3,90$ \\
3 & $230,53 \pm 5,13$ & $218,80 \pm 4,21$ \\
5 & $233,80 \pm 5,11$ & $219,37 \pm 4,05^{\star}$ \\
8 & $234,00 \pm 4,90$ & $220,87 \pm 4,19$ \\
10 & $236,33 \pm 4,82$ & $222,07 \pm 3,93^{\star}$ \\
12 & $236,73 \pm 4,94$ & $223,27 \pm 3,97^{\star}$ \\
15 & $237,87 \pm 4,81$ & $224,13 \pm 3,87^{\star}$ \\
17 & $237,33 \pm 5,00$ & $221,33 \pm 3,91^{\star}$ \\
19 & $239,60 \pm 4,65$ & $227,13 \pm 4,03$ \\
22 & $242,67 \pm 4,95$ & $229,33 \pm 4,25$ \\
24 & $241,93 \pm 4,83$ & $228,73 \pm 4,31$ \\
26 & $241,13 \pm 4,84$ & $226,40 \pm 4,33^{\star}$ \\
29 & $244,87 \pm 4,80$ & $230,67 \pm 4,49^{\star}$ \\
31 & $246,60 \pm 4,73$ & $232,40 \pm 4,60^{\star}$ \\
33 & $239,40 \pm 4,51$ & $225,80 \pm 4,30^{\star}$ \\
36 & $247,53 \pm 4,80$ & $234,13 \pm 5,00$ \\
Ganho de peso & $17,87 \pm 1,93$ & $15,60 \pm 1,92$ \\
\hline
\end{tabular}

* $p<0,05$, teste $t$. 


\section{fêmeas}

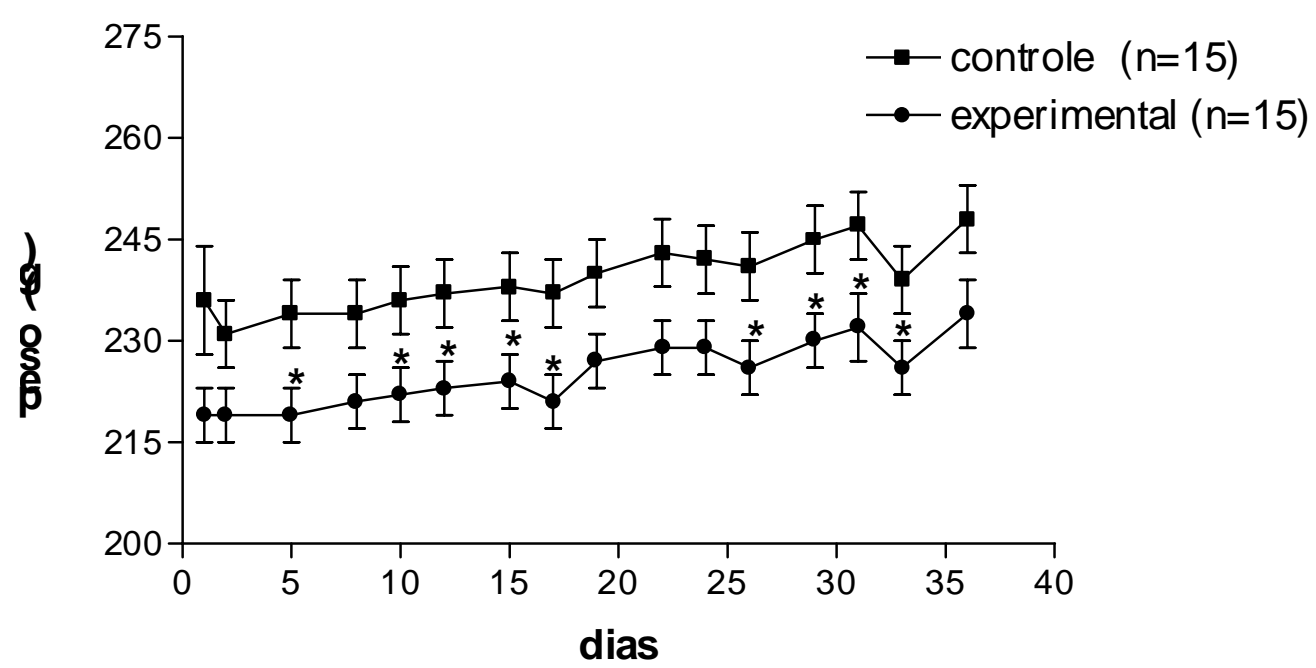

Figura 2. Peso de ratos que receberam, por 36 dias, $3 \%$ de Solanum lycocarpum na ração ou apenas ração moída (controle). São apresentadas as médias e os respectivos erros padrões.

${ }^{*} \mathrm{p}<0,05$, test t. 
Tabela 2. Consumo médio de ração (em g) e de água (em $\mathrm{ml}$ ) de ratas que receberam, por 36 dias, 3\% de Solanum lycocarpum na ração ou apenas ração moída (controle). São apresentadas as médias e os respectivos erros padrões.

\begin{tabular}{|c|c|c|c|c|}
\hline \multirow[t]{2}{*}{ Dia } & \multicolumn{2}{|c|}{ Consumo de ração (g) } & \multicolumn{2}{|c|}{ Consumo de água (ml) } \\
\hline & $\begin{array}{l}\text { Controle } \\
(n=15)\end{array}$ & $\begin{array}{c}\text { Experimental } \\
(n=15)\end{array}$ & $\begin{array}{c}\text { Controle } \\
(\mathrm{n}=15)\end{array}$ & $\begin{array}{c}\text { Experimental } \\
(n=15)\end{array}$ \\
\hline 2 & $43,5 \pm 5,8$ & $47,4 \pm 0,6$ & $32,3 \pm 1,5$ & $20,7 \pm 1,3^{*}$ \\
\hline 3 & $44,1 \pm 5,2$ & $53,5 \pm 5,0$ & $30,7 \pm 1,5$ & $25,7 \pm 0,7^{*}$ \\
\hline 4 & $40,9 \pm 8,2$ & $40,3 \pm 6,6$ & $30,3 \pm 0,3$ & $25,0 \pm 1,2^{*}$ \\
\hline 5 & $38,2 \pm 4,0$ & $42,2 \pm 8,9$ & $35,0 \pm 1,5$ & $31,3 \pm 1,9$ \\
\hline 6 & $31,9 \pm 4,2$ & $24,3 \pm 3,8$ & $29,0 \pm 2,1$ & $25,0 \pm 0,6$ \\
\hline 7 & $38,3 \pm 1,7$ & $32,1 \pm 3,7$ & $34,0 \pm 0,6$ & $32,3 \pm 0,9$ \\
\hline 8 & $23,9 \pm 3,9$ & $26,6 \pm 4,5$ & $30,3 \pm 2,2$ & $27,0 \pm 1,2$ \\
\hline 9 & $27,6 \pm 0,3$ & $27,5 \pm 3,0$ & $28,7 \pm 1,2$ & $26,0 \pm 1,0$ \\
\hline 10 & $34,7 \pm 3,2$ & $33,5 \pm 7,8$ & $29,0 \pm 1,5$ & $26,3 \pm 1,7$ \\
\hline 11 & $39,1 \pm 5,5$ & $31,3 \pm 6,3$ & $35,3 \pm 1,7$ & $32,3 \pm 1,3$ \\
\hline 12 & $31,5 \pm 6,0$ & $35,1 \pm 8,5$ & $30,7 \pm 0,3$ & $27,0 \pm 0,6^{*}$ \\
\hline 13 & $30,9 \pm 3,5$ & $23,7 \pm 2,1$ & $32,7 \pm 1,5$ & $28,3 \pm 0,9$ \\
\hline 14 & $36,2 \pm 6,3$ & $37,0 \pm 5,7$ & $33,0 \pm 1,7$ & $28,7 \pm 2,0$ \\
\hline 15 & $30,3 \pm 2,8$ & $33,5 \pm 6,2$ & $33,0 \pm 2,0$ & $29,3 \pm 1,2$ \\
\hline 16 & $25,9 \pm 2,0$ & $36,8 \pm 3,6$ & $30,0 \pm 0,0$ & $26,7 \pm 0,9$ \\
\hline 17 & $37,4 \pm 6,0$ & $32,2 \pm 2,5$ & $39,0 \pm 2,1$ & $30,0 \pm 2,0^{*}$ \\
\hline 18 & $32,3 \pm 3,1$ & $32,3 \pm 3,2$ & $36,7 \pm 0,3$ & $34,0 \pm 3,1$ \\
\hline 19 & $25,9 \pm 1,1$ & $36,3 \pm 4,4$ & $30,0 \pm 1,0$ & $30,7 \pm 0,7$ \\
\hline 20 & $28,1 \pm 2,8$ & $31,4 \pm 6,3$ & $30,7 \pm 0,3$ & $26,3 \pm 1,2^{\star}$ \\
\hline 21 & $29,7 \pm 1,3$ & $43,1 \pm 8,0$ & $34,7 \pm 2,2$ & $29,0 \pm 1,0$ \\
\hline 22 & $27,5 \pm 2,5$ & $27,4 \pm 5,3$ & $34,0 \pm 1,5$ & $31,0 \pm 0,6$ \\
\hline 23 & $32,9 \pm 3,0$ & $36,8 \pm 7,4$ & $29,3 \pm 0,9$ & $25,7 \pm 0,9^{*}$ \\
\hline 24 & $30,9 \pm 3,2$ & $43,0 \pm 6,4$ & $33,0 \pm 1,5$ & $30,3 \pm 0,7$ \\
\hline 25 & $26,8 \pm 0,3$ & $42,7 \pm 4,4^{*}$ & $32,3 \pm 1,8$ & $30,0 \pm 1,2$ \\
\hline 26 & $35,6 \pm 6,0$ & $45,0 \pm 3,4$ & $32,7 \pm 0,3$ & $29,3 \pm 2,0$ \\
\hline 27 & $33,9 \pm 3,1$ & $40,7 \pm 3,5$ & $28,0 \pm 1,0$ & $25,3 \pm 0,3$ \\
\hline 28 & $37,1 \pm 7,1$ & $44,8 \pm 3,9$ & $34,7 \pm 2,0$ & $31,0 \pm 1,2$ \\
\hline 29 & $35,1 \pm 3,2$ & $43,4 \pm 2,6$ & $36,3 \pm 2,0$ & $32,3 \pm 1,2$ \\
\hline 30 & $31,8 \pm 5,9$ & $34,8 \pm 2,1$ & $29,3 \pm 1,2$ & $27,0 \pm 1,0$ \\
\hline 31 & $28,7 \pm 6,3$ & $41,0 \pm 0,4$ & $34,3 \pm 0,7$ & $28,3 \pm 1,8^{\star}$ \\
\hline 32 & $40,2 \pm 9,3$ & $42,7 \pm 3.7$ & $33,0 \pm 1,7$ & $31,3 \pm 1,2$ \\
\hline 33 & $41,0 \pm 2,9$ & $40,1 \pm 2,0$ & $36,3 \pm 0,9$ & $31,3 \pm 1,3^{*}$ \\
\hline 34 & $36,9 \pm 3,2$ & $35,9 \pm 4,1$ & $32,0 \pm 1,5$ & $26,7 \pm 1,2$ \\
\hline 35 & $24,9 \pm 1,9$ & $26,3 \pm 2,0$ & $33,3 \pm 1,9$ & $27,7 \pm 1,8$ \\
\hline 36 & $40,2 \pm 6,6$ & $40,2 \pm 2,1$ & $33,7 \pm 0,9$ & $31,7 \pm 1,9$ \\
\hline
\end{tabular}




\section{fêmeas}

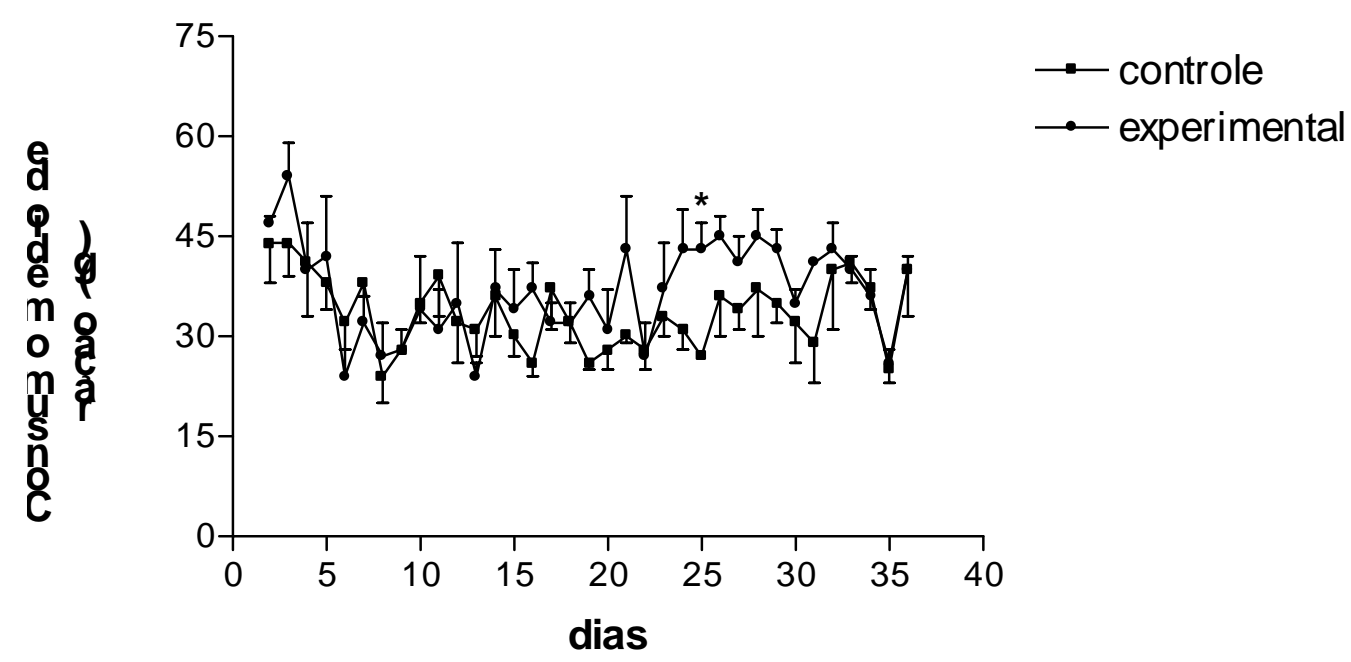

fêmeas

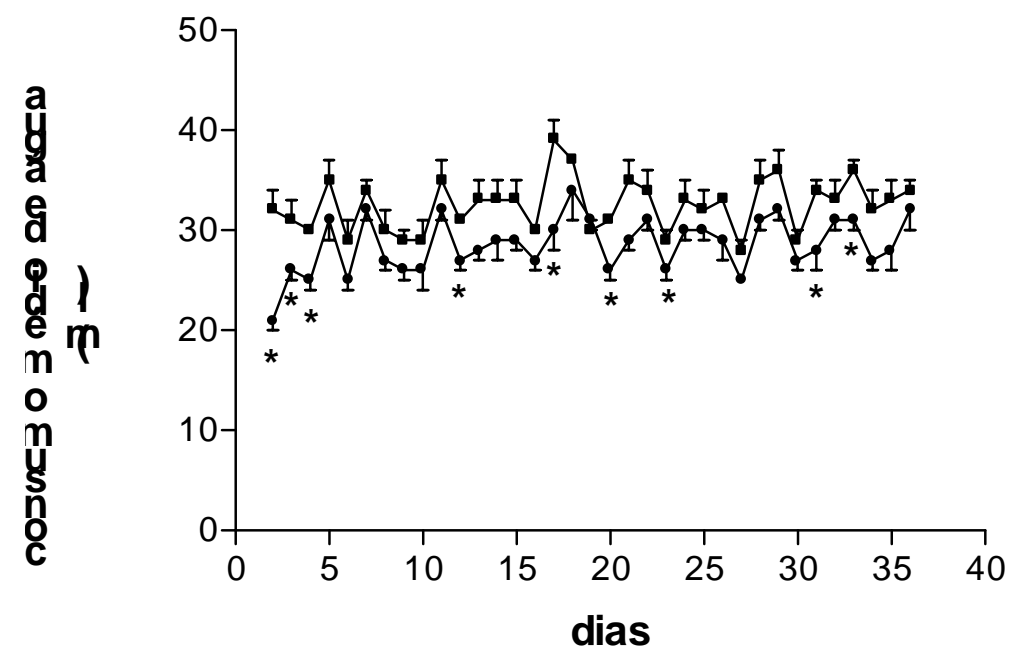

Figura 3. Consumo médio de ração e de água de ratas que receberam 3\% de Solanum lycocarpum $(n=15)$ na ração ou apenas ração moída (controle: $\mathrm{n}=15$ ). São apresentadas as médias e os respectivos erros padrões.

${ }^{*} p<0,05$, teste t. 
Tabela 3. Intervalo entre ciclos e número de dias em cada fase do ciclo estral, avaliado durante 20 dias, em ratas que receberam do $17^{\circ}$ ao $37^{\circ}$ dia, 3\% de Solanum lycocarpum na ração ou apenas ração moída (controle). São apresentadas as médias e os respectivos erros padrões.

\begin{tabular}{lcc}
\hline Fase do ciclo estral & Controle $(\mathrm{n}=15)$ & S. lycocarpum $(\mathrm{n}=15)$ \\
\hline Pró-estro & $6,4 \pm 0,5$ & $6,3 \pm 0,7$ \\
Estro & $4,3 \pm 0,4$ & $4,5 \pm 0,3$ \\
Metaestro & $4,9 \pm 0,5$ & $5,8 \pm 0,5$ \\
Diestro & $5,5 \pm 0,7$ & $4,3 \pm 0,8$ \\
Intervalo entre ciclos & $5,5 \pm 0,2$ & $4,8 \pm 0,3$ \\
\hline
\end{tabular}

$p>0,05$, teste $t$. 
Tabela 4. Peso dos órgãos de ratas que receberam, por no mínimo 37 dias, 3\% de Solanum lycocarpum na ração ou apenas ração moída (controle). São apresentadas as médias e os respectivos erros padrões.

\begin{tabular}{lcc}
\hline Órgão & Controle $(\mathrm{n}=15)$ & S. lycocarpum $(\mathrm{n}=15)$ \\
\hline Útero $(\mathrm{mg})$ & $470,4 \pm 33,26$ & $382,3 \pm 19,60^{*}$ \\
Adrenal direita (mg) & $40,74 \pm 2,80$ & $38,21 \pm 2,19$ \\
Adrenal esquerda (mg) & $41,30 \pm 2,72$ & $38,39 \pm 1,75$ \\
Ovário direito (mg) & $70,71 \pm 4,47$ & $66,53 \pm 3,83$ \\
Ovário esquerdo (mg) & $67,02 \pm 4,62$ & $66,71 \pm 5,78$ \\
Fígado (g) & $8,97 \pm 0,17$ & $8,20 \pm 0,17 *$ \\
\hline *p<0,05, teste t. & &
\end{tabular}


Tabela 5. Valores de alanina amimotransferase (ALT), aspartato aminotransferase (AST), albumina, creatinina, fosfatase alcalina e proteínas totais de ratas que receberam, por no mínimo 37 dias, 3\% de Solanum lycocarpum na ração ou apenas ração moída (controle). São apresentadas as médias e os respectivos erros padrões.

\begin{tabular}{lcc}
\hline & Controle $(\mathrm{n}=15)$ & S. lycocarpum $(\mathrm{n}=15)$ \\
\hline ALT $(\mathrm{U} / \mathrm{l})$ & $41,405 \pm 4,559$ & $37,202 \pm 2,151$ \\
AST $(\mathrm{U} / \mathrm{l})$ & $110,94 \pm 9,348$ & $97,235 \pm 10,702$ \\
Albumina $(\mathrm{g} / \mathrm{dl})$ & $3,892 \pm 0,387$ & $3,444 \pm 0,329$ \\
Creatinina $(\mathrm{mg} / \mathrm{l})$ & $0,709 \pm 0,073$ & $0,706 \pm 0,042$ \\
Fosfatase alcalina $(\mathrm{U} / \mathrm{l})$ & $31,343 \pm 2,701$ & $35,094 \pm 3,650$ \\
Proteínas totais $(\mathrm{mmol} / \mathrm{l})$ & $16,366 \pm 0,450$ & $16,422 \pm 0,504$ \\
\hline p $>0,05$, teste t. & &
\end{tabular}



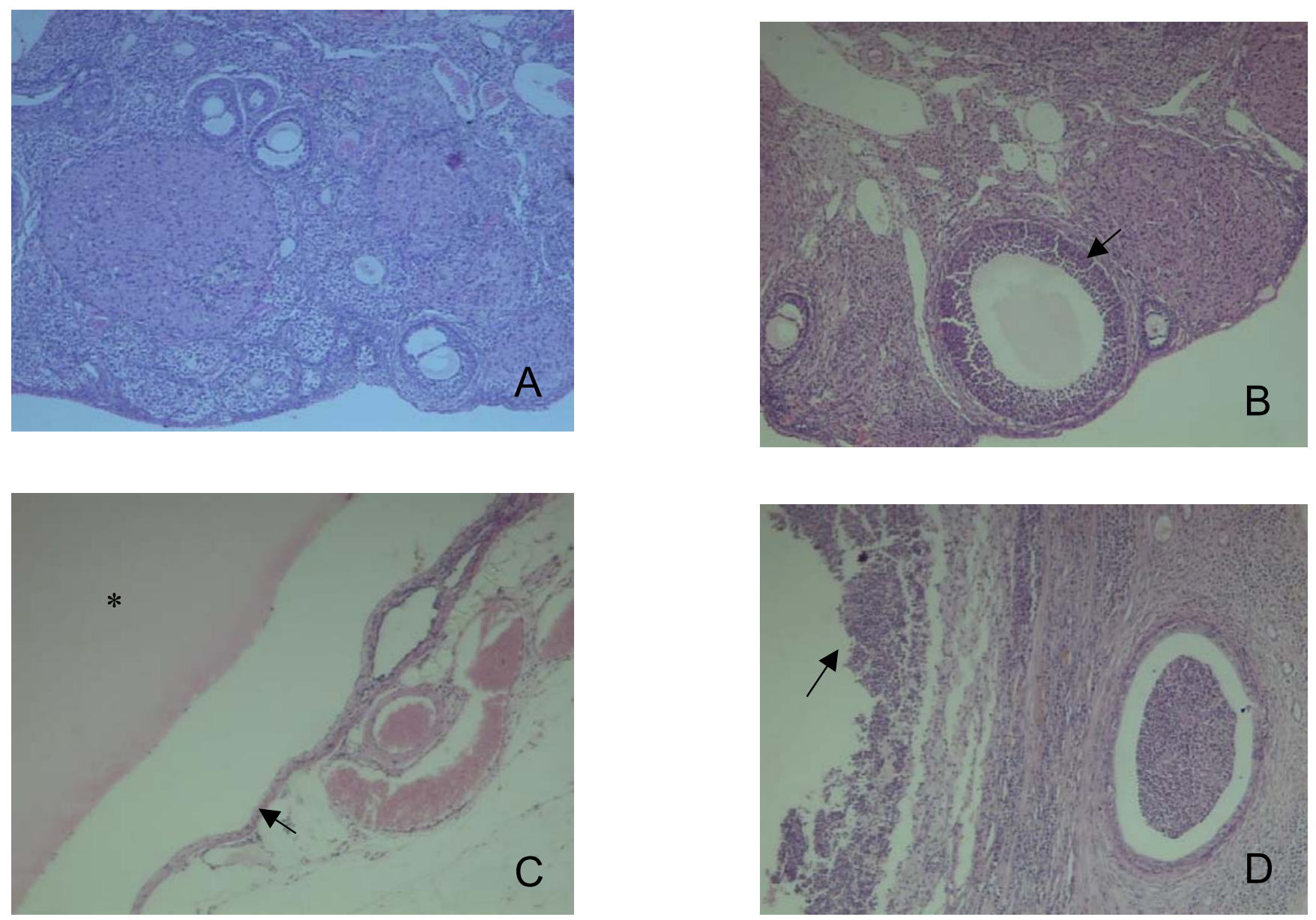

Figura 4. A)Ovário animal controle (HE 4X) B) Ovário, de uma rata que recebeu S. lycocarpum a 3\% na ração, com pequeno cisto folicular repleto de substância eosinofílica semelhante a colóide (seta) (HE 4X). C) Parede do cisto folicular (seta), repleto de substância eosinofílica semelhande a colóide ${ }^{*}$ ) (HE 4X). D) Cisto folicular com grande quantidade de células na parede interna do cisto (seta) (HE 4X). 

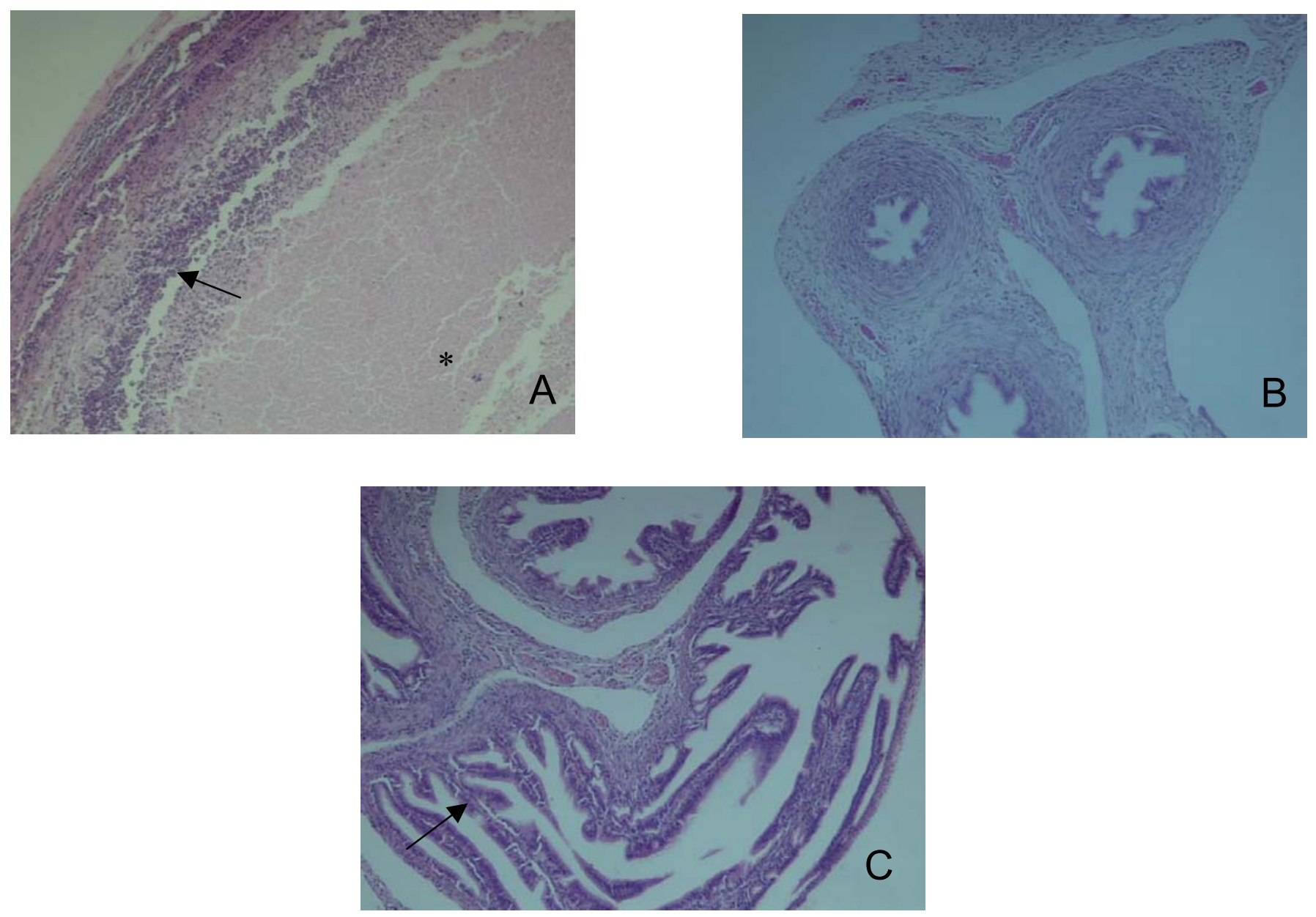

Figura 5. A) Grande cisto folicular com interior repleto de material necrótico $\left(^{*}\right)$. Parede interna de evestimento formada por células foliculares (seta) (4X). B) Revestimento endometrial em oviduto em femea controle (HE 4X). C) Hiperplasia de endométrio (seta) em oviduto de animal tratado durante 37 dias com a Solanum lycocarpum a 3\% na ração (HE 4X). 

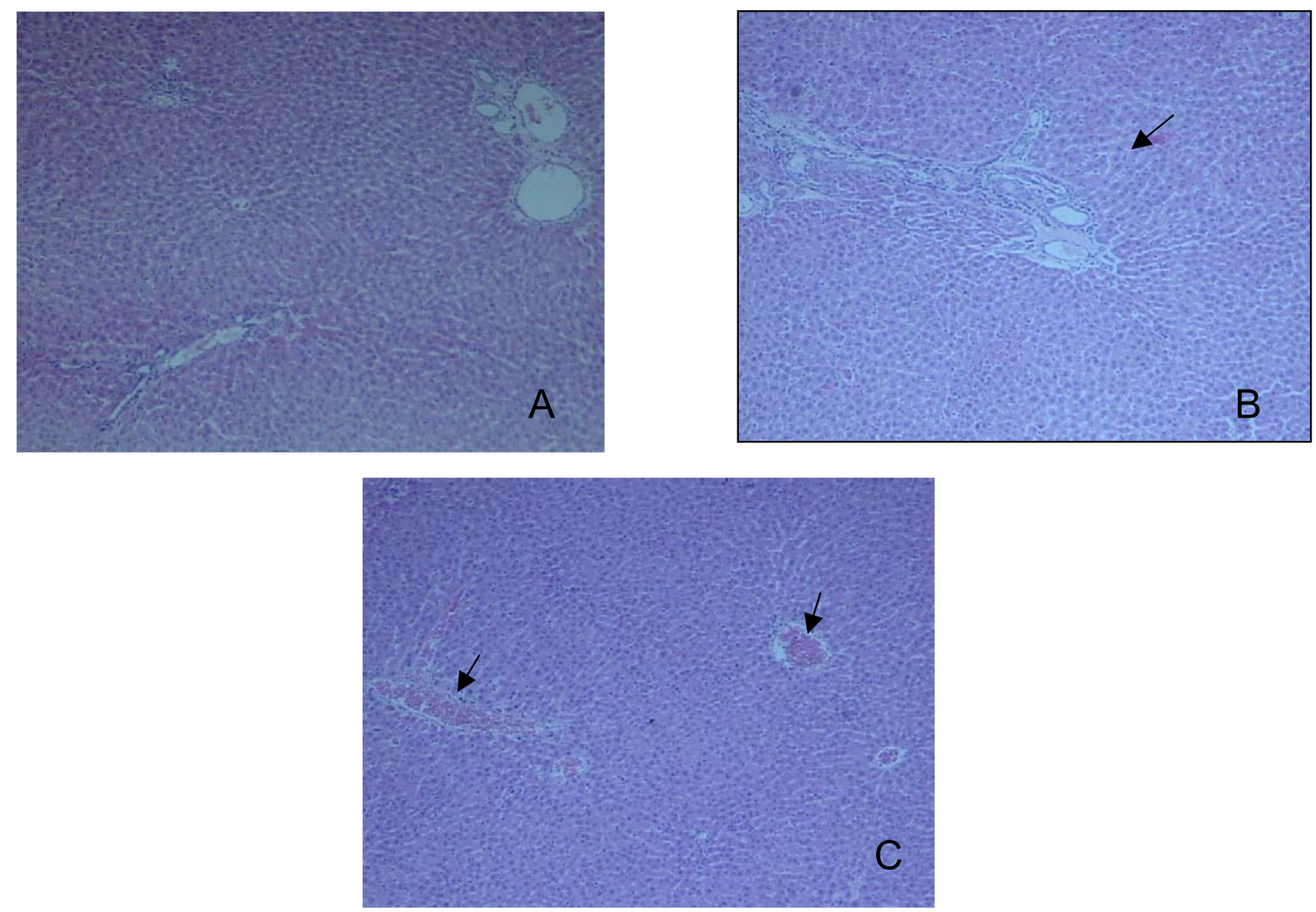

Figura 6. A) Fígado animal controle (HE 4X). B) Fígado apresentando proliferação de ductos biliares (seta) (HE 4X). C) Congestão hepática (seta) (HE 4X). 

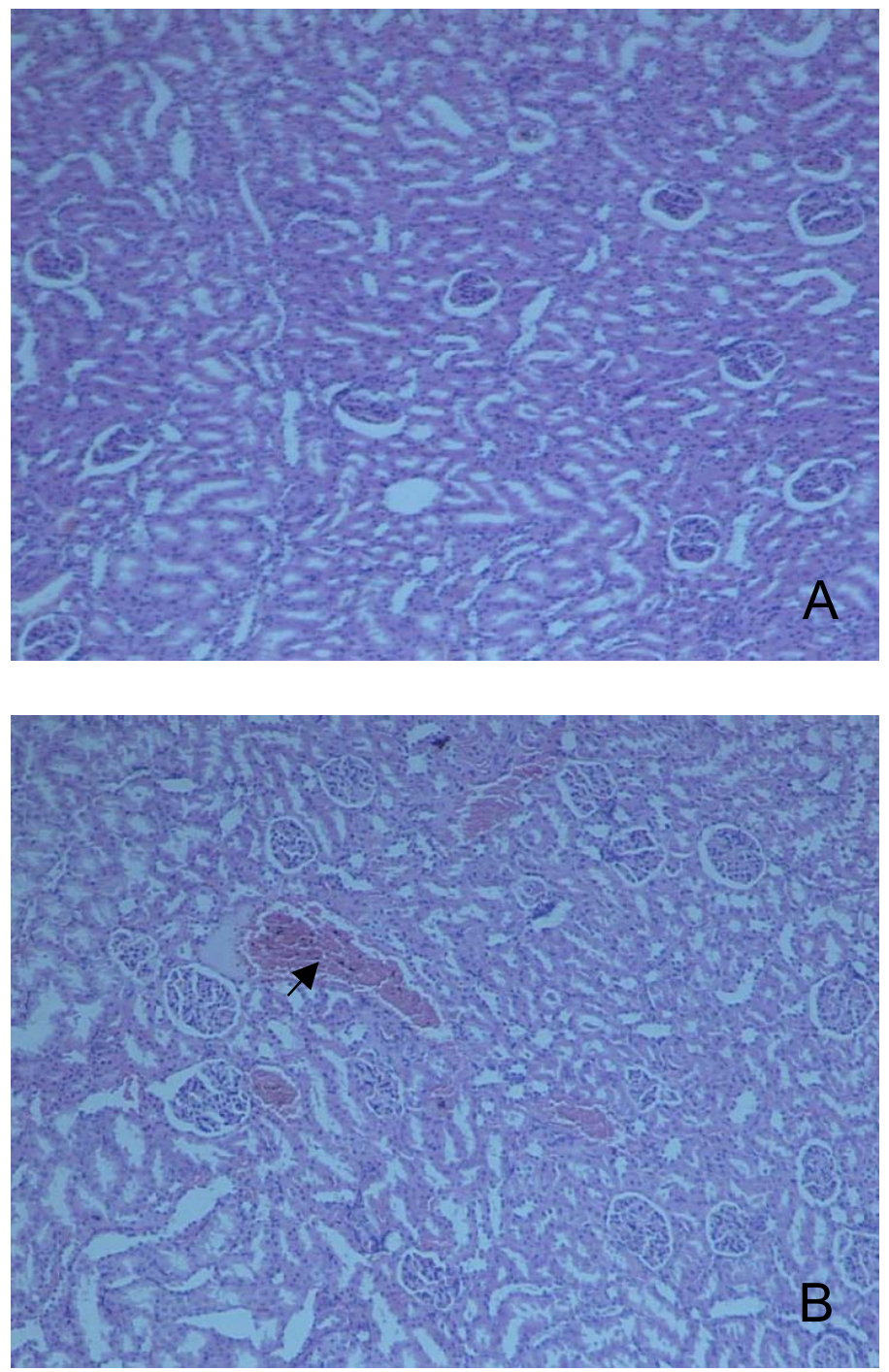

Figura 7. A) Rim animal controle (HE 4X). B) Congestão renal (seta) (HE 4X). 


\subsection{Experimento 2. Efeitos do consumo de S. lycocarpum em ratos adultos.}

Foram utilizados 19 machos com 90 dias de idade, os quais foram divididos em 2 grupos: um controle $(n=10)$ e um experimental $(n=9)$. Os animais do grupo experimental receberam 3\% de S. lycocarpum adicionada à ração moída, por 60 dias, enquanto os animais do grupo controle receberam ração moída durante o mesmo período de tempo, conforme descrito no item 3.2. Os animais foram pesados a cada 2-3 dias e o ganho de peso avaliado entre o $3^{\circ}$ e $60^{\circ}$ dia de tratamento. $O$ consumo médio de ração e água por gaiola foi avaliado diariamente, durante 60 dias de tratamento.

Após 60 dias, os animais foram submetidos à anestesia por inalação de éter e retirou-se o sangue para determinação dos níveis séricos de enzimas e proteínas, conforme descrito no item 3.3.2. Foi feita também a retirada de órgãos (vesícula seminal, adrenais, testículos, fígado, pulmão, rins, estômago e intestino) para a pesagem e/ou realização do exame anatomopatológico, conforme itens 3.3.3. e 3.3.4.

A Tab. 6 e a Fig. 8 mostram o peso e ganho de peso de ratos que receberam 3\% de S. lycocarpum na ração. Assim, nota-se que não foram observadas diferenças significantes no peso e no ganho de peso dos ratos machos dos grupos controle e experimental.

A Tab. 7 e a Fig. 9 mostram o consumo médio de ração e água dos ratos que receberam dieta contendo 3\% S. lycocarpum. Assim, nota-se 
aumento no consumo médio de ração dos ratos do grupo experimental nos dias 14 e 18 do tratamento e redução no dia 23, quando comparado ao grupo controle. Quanto ao consumo de água, observou-se redução no consumo médio de água dos animais do grupo experimental apenas no $48^{\circ}$ dia de tratamento, quando comparado com aqueles do grupo controle.

A Tab. 8 mostra o peso de diferentes órgão de ratos que receberam a planta por 60 dias na ração. Assim, nota-se ausência de diferenças significantes entre os grupos.

A Tab. 9 mostra os efeitos do tratamento com 3\% de S. Iycocarpum adicionada à dieta, em parâmetros séricos dos ratos. Assim, nota-se que não houve diferenças significantes entre os animais dos dois grupos nos valores de ALT, AST, albumina, creatinina, fosfatase alcalina e proteínas totais.

O estudo anatomopatológico dos órgãos de ratos que receberam dieta contendo 3\% de S. lycocarpum não mostrou alterações dignas de nota. 
Tabela 6. Peso e ganho de peso (em gramas) de ratos que receberam, por 60 dias, 3\% de Solanum lycocarpum na ração ou apenas ração moída (controle). São apresentadas as médias e os respectivos erros padrões.

\begin{tabular}{ccc}
\hline Dia & Controle $(\mathrm{n}=10)$ & S. lycocarpum $(\mathrm{n}=9)$ \\
\hline 3 & $334,60 \pm 7,28$ & $337,56 \pm 7,75$ \\
5 & $341,00 \pm 6,82$ & $342,67 \pm 8,32$ \\
7 & $345,5 \pm 7,61$ & $347,22 \pm 8,22$ \\
9 & $349,10 \pm 7,88$ & $351,11 \pm 8,61$ \\
11 & $351,70 \pm 8,31$ & $353,44 \pm 8,40$ \\
14 & $361,10 \pm 8,66$ & $358,78 \pm 9,42$ \\
16 & $365,50 \pm 9,04$ & $361,67 \pm 9,31$ \\
18 & $370,20 \pm 9,26$ & $367,89 \pm 10,19$ \\
21 & $377,10 \pm 9,07$ & $372,00 \pm 9,52$ \\
23 & $374,90 \pm 9,20$ & $371,89 \pm 9,25$ \\
25 & $373,80 \pm 9,07$ & $372,44 \pm 9,16$ \\
28 & $376,10 \pm 9,30$ & $372,22 \pm 9,73$ \\
30 & $378,90 \pm 8,99$ & $375,44 \pm 9,89$ \\
32 & $374,30 \pm 9,78$ & $370,67 \pm 10,58$ \\
35 & $381,90 \pm 9,80$ & $376,11 \pm 11,90$ \\
37 & $378,50 \pm 9,41$ & $375,11 \pm 10,67$ \\
39 & $387,20 \pm 9,61$ & $381,33 \pm 11,75$ \\
42 & $390,00 \pm 10,33$ & $378,78 \pm 11,19$ \\
44 & $390,30 \pm 10,48$ & $385,33 \pm 11,18$ \\
46 & $395,60 \pm 10,40$ & $388,33 \pm 11,59$ \\
49 & $387,30 \pm 10,71$ & $385,33 \pm 12,05$ \\
51 & $394,60 \pm 10,53$ & $392,22 \pm 11,91$ \\
53 & $397,50 \pm 10,99$ & $392,00 \pm 11,27$ \\
56 & $399,00 \pm 10,97$ & $392,22 \pm 10,73$ \\
58 & $403,60 \pm 11,28$ & $394,78 \pm 11,60$ \\
60 & $394,50 \pm 11,85$ & $395,22 \pm 11,85$ \\
Ganho de peso & $59,9 \pm 6,71$ & $57,67 \pm 8,04$ \\
\hline
\end{tabular}

$p>0,05$, teste $t$ 


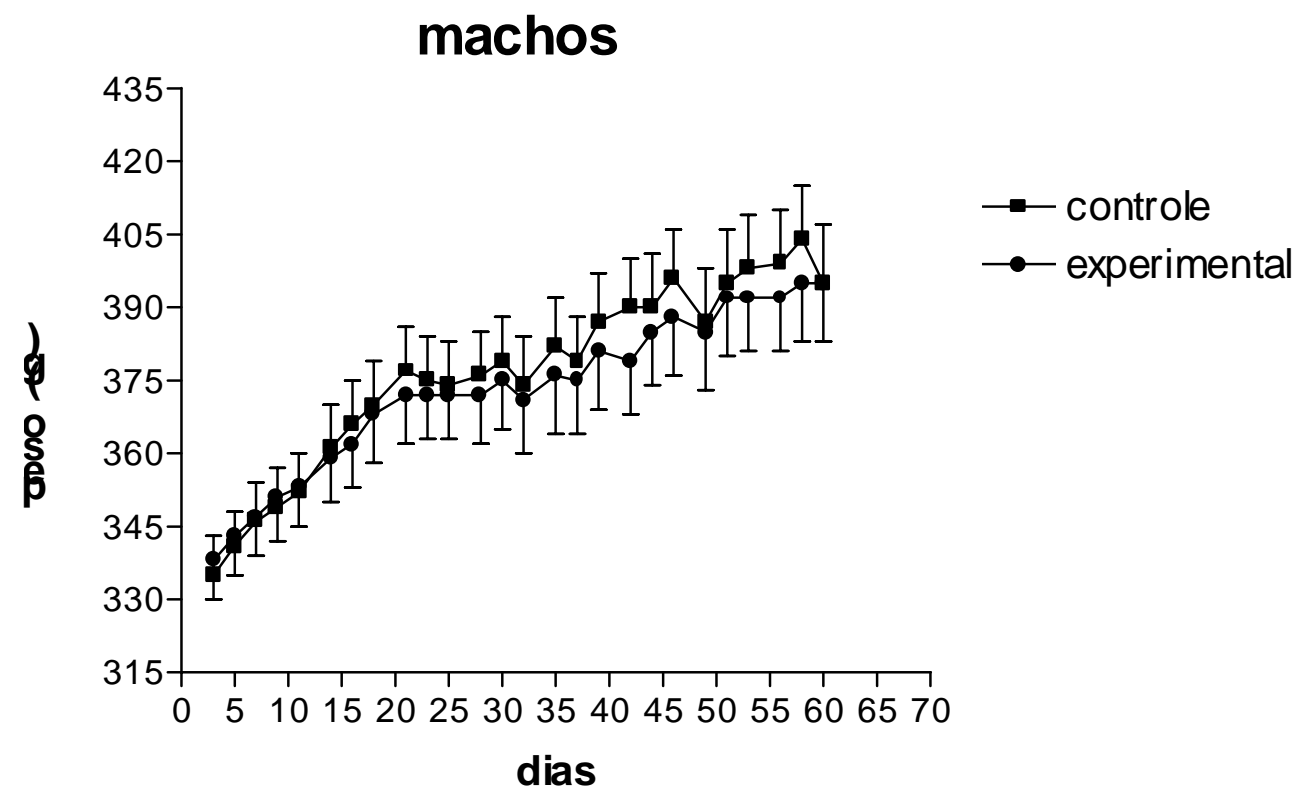

Figura 8. Peso de ratos que receberam, por 60 dias, $3 \%$ de Solanum lycocarpum na ração ou apenas ração moída (controle). São apresentadas as médias e os respectivos erros padrões.

* $p<0,05$, test t. 
Tabela 7. Consumo médio de ração (em g) e de água (em $\mathrm{ml}$ ) por rato que recebeu, por 60 dias, 3\% de Solanum lycocarpum na ração ou apenas ração moída (controle). São apresentadas as média e os respectivos erros padrões (cont.)

\begin{tabular}{|c|c|c|c|c|}
\hline \multirow[t]{2}{*}{ Dia } & \multicolumn{2}{|c|}{ Consumo de ração $(\mathrm{g})$} & \multicolumn{2}{|c|}{ Consumo de água (ml) } \\
\hline & $\begin{array}{c}\text { Controle } \\
(n=10)\end{array}$ & $\begin{array}{l}\text { Experimental } \\
(n=9)\end{array}$ & $\begin{array}{c}\text { Controle } \\
(n=10)\end{array}$ & $\begin{array}{l}\text { Experimental } \\
(n=9)\end{array}$ \\
\hline 2 & $42,7 \pm 1,3$ & $42,2 \pm 1,4$ & $36,0 \pm 2,0$ & $31,0 \pm 1,0$ \\
\hline 3 & $50,2 \pm 9,6$ & $49,1 \pm 0,9$ & $37,5 \pm 0,5$ & $32,5 \pm 2,5$ \\
\hline 4 & $33,1 \pm 1,9$ & $33,8 \pm 2,0$ & $40,5 \pm 0,5$ & $34,5 \pm 2,5$ \\
\hline 5 & $39,8 \pm 3,0$ & $40,1 \pm 1,7$ & $40,0 \pm 3,0$ & $38,0 \pm 2,0$ \\
\hline 6 & $30,4 \pm 4,0$ & $30,6 \pm 2,0$ & $36,5 \pm 0,5$ & $33,5 \pm 1,5$ \\
\hline 7 & $38,5 \pm 0,7$ & $40,7 \pm 4,7$ & $48,0 \pm 1,0$ & $46,5 \pm 0,5$ \\
\hline 8 & $31,7 \pm 3,1$ & $27,9 \pm 1,1$ & $36,0 \pm 1,0$ & $35,0 \pm 4,0$ \\
\hline 9 & $38,8 \pm 3,2$ & $24,9 \pm 0,5$ & $38,0 \pm 0,0$ & $36,0 \pm 4,0$ \\
\hline 10 & $39,7 \pm 3,5$ & $37,1 \pm 7,1$ & $39,0 \pm 1,0$ & $37,0 \pm 2,0$ \\
\hline 11 & $29,8 \pm 0,2$ & $31,2 \pm 2,8$ & $42,0 \pm 2,0$ & $40,5 \pm 4,5$ \\
\hline 12 & $32,6 \pm 1,2$ & $41,4 \pm 8,6$ & $37,0 \pm 0,0$ & $36,5 \pm 4,5$ \\
\hline 13 & $39,2 \pm 5,6$ & $38,8 \pm 6,2$ & $42,5 \pm 0,5$ & $42,0 \pm 1,0$ \\
\hline 14 & $32,1 \pm 0,1$ & $38,8 \pm 1,6^{\star}$ & $40,0 \pm 2,0$ & $40,0 \pm 2,0$ \\
\hline 15 & $33,3 \pm 4,9$ & $34,0 \pm 3,6$ & $45,5 \pm 5,5$ & $40,5 \pm 3,5$ \\
\hline 16 & $37,4 \pm 5,0$ & $41,7 \pm 11,1$ & $36,5 \pm 0,5$ & $36,5 \pm 5,5$ \\
\hline 17 & $47,6 \pm 5,0$ & $35,1 \pm 2,7$ & $42,5 \pm 1,5$ & $40,5 \pm 3,5$ \\
\hline 18 & $37,8 \pm 1,6$ & $50,8 \pm 1,8^{*}$ & $43,0 \pm 0,0$ & $41,5 \pm 3,5$ \\
\hline 19 & $45,3 \pm 4,5$ & $43,5 \pm 3,5$ & $48,0 \pm 11,0$ & $38,5 \pm 4,5$ \\
\hline 20 & $39,6 \pm 8,6$ & $45,7 \pm 10,5$ & $42,0 \pm 5,0$ & $37,0 \pm 3,0$ \\
\hline 21 & $52,2 \pm 3,6$ & $43,7 \pm 9,5$ & $55,0 \pm 15,0$ & $40,0 \pm 3,0$ \\
\hline 22 & $49,5 \pm 5,3$ & $49,7 \pm 6,9$ & $42,0 \pm 2,0$ & $38,0 \pm 4,0$ \\
\hline 23 & $53,3 \pm 0,1$ & $46,7 \pm 1,1^{*}$ & $38,5 \pm 4,5$ & $35,0 \pm 3,0$ \\
\hline 24 & $54,8 \pm 1,0$ & $51,0 \pm 11,6$ & $39,5 \pm 0,5$ & $35,5 \pm 3,5$ \\
\hline 25 & $45,3 \pm 7,5$ & $53,8 \pm 11,6$ & $47,0 \pm 4,0$ & $36,5 \pm 5,5$ \\
\hline 26 & $50,8 \pm 3,2$ & $46,1 \pm 12,9$ & $36,5 \pm 2,5$ & $34,5 \pm 0,5$ \\
\hline 27 & $43,3 \pm 1,1$ & $42,7 \pm 3,3$ & $39,0 \pm 1,5$ & $31,5 \pm 3,5$ \\
\hline 28 & $53,1 \pm 1,1$ & $49,8 \pm 8,2$ & $39,0 \pm 1,0$ & $36,0 \pm 4,0$ \\
\hline 29 & $46,0 \pm 7,6$ & $56,3 \pm 21,7$ & $39,5 \pm 1,5$ & $40,5 \pm 0,5$ \\
\hline 30 & $50,6 \pm 0,2$ & $51,2 \pm 8,6$ & $39,5 \pm 0,5$ & $35,5 \pm 1,5$ \\
\hline 31 & $42,6 \pm 8,8$ & $47,1 \pm 11,1$ & $36,0 \pm 3,0$ & $35,0 \pm 2,0$ \\
\hline 32 & $50,7 \pm 0,5$ & $58,7 \pm 15,3$ & $42,0 \pm 2,0$ & $38,0 \pm 4,0$ \\
\hline 33 & $47,2 \pm 9,6$ & $41,7 \pm 6,7$ & $42,0 \pm 1,0$ & $32,5 \pm 2,5$ \\
\hline
\end{tabular}


Tabela 7. Consumo médio de ração (em g) e de água (em $\mathrm{ml}$ ) por rato que recebeu, por 60 dias, 3\% de Solanum lycocarpum na ração ou apenas ração moída (controle). São apresentadas as média e os respectivos erros padrões. (cont).

\begin{tabular}{|c|c|c|c|c|}
\hline \multirow[t]{2}{*}{ Dia } & \multicolumn{2}{|c|}{ Consumo de ração (g) } & \multicolumn{2}{|c|}{ Consumo de água (ml) } \\
\hline & $\begin{array}{c}\text { Controle } \\
(\mathrm{n}=10)\end{array}$ & $\begin{array}{c}\text { Experimental } \\
(\mathrm{n}=9)\end{array}$ & $\begin{array}{c}\text { Controle } \\
(n=10)\end{array}$ & $\begin{array}{c}\text { Experimental } \\
(\mathrm{n}=9)\end{array}$ \\
\hline 34 & $45,2 \pm 0,6$ & $45,7 \pm 4,3$ & $41,0 \pm 2,0$ & $35,5 \pm 4,5$ \\
\hline 35 & $43,0 \pm 1,2$ & $47,4 \pm 0,9$ & $38,5 \pm 2,5$ & $38,5 \pm 3,5$ \\
\hline 36 & $42,3 \pm 8,9$ & $55,4 \pm 15,6$ & $38,5 \pm 1,5$ & $38,0 \pm 5,0$ \\
\hline 37 & $50,6 \pm 1,8$ & $59,0 \pm 13,8$ & $48,0 \pm 0,0$ & $44,5 \pm 2,5$ \\
\hline 38 & $45,3 \pm 0,3$ & $31,5 \pm 8,9$ & $30,0 \pm 2,0$ & $29,0 \pm 4,0$ \\
\hline 39 & $34,8 \pm 12,4$ & $50,8 \pm 11,6$ & $40,0 \pm 0,0$ & $37,0 \pm 2,0$ \\
\hline 40 & $45,0 \pm 6,8$ & $51,6 \pm 6,4$ & $39,5 \pm 1,5$ & $35,5 \pm 0,5$ \\
\hline 41 & $52,0 \pm 0,2$ & $56,9 \pm 10,5$ & $39,0 \pm 0,0$ & $36,0 \pm 3,0$ \\
\hline 42 & $54,3 \pm 2,3$ & $55,2 \pm 1,4$ & $41,0 \pm 0,0$ & $36,0 \pm 2,0$ \\
\hline 43 & $47,9 \pm 9,1$ & $61,2 \pm 6,6$ & $42,5 \pm 3,5$ & $31,5 \pm 10,5$ \\
\hline 44 & $43,2 \pm 10,8$ & $63,2 \pm 7,6$ & $38,0 \pm 2,0$ & $37,0 \pm 1,0$ \\
\hline 45 & $58,1 \pm 0,3$ & $59,9 \pm 16,9$ & $39,5 \pm 2,5$ & $36,5 \pm 3,5$ \\
\hline 46 & $55,6 \pm 0,2$ & $54,6 \pm 20,4$ & $36,0 \pm 2,0$ & $35,0 \pm 2,0$ \\
\hline 47 & $53,8 \pm 1,6$ & $62,4 \pm 11,0$ & $34,5 \pm 7,5$ & $36,0 \pm 2,0$ \\
\hline 48 & $55,2 \pm 3,6$ & $66,1 \pm 7,9$ & $44,0 \pm 1,0$ & $35,5 \pm 1,5^{\star}$ \\
\hline 49 & $46,9 \pm 6,7$ & $52,8 \pm 13,0$ & $44,5 \pm 2,5$ & $44,0 \pm 6,0$ \\
\hline 50 & $53,8 \pm 3,0$ & $58,0 \pm 9,4$ & $45,5 \pm 1,5$ & $44,5 \pm 0,5$ \\
\hline 51 & $49,4 \pm 2,0$ & $49,1 \pm 11,9$ & $40,0 \pm 1,0$ & $36,0 \pm 1,0$ \\
\hline 52 & $49,8 \pm 2,8$ & $50,4 \pm 13,2$ & $34,5 \pm 0,5$ & $31,5 \pm 1,5$ \\
\hline 53 & $46,6 \pm 1,8$ & $43,2 \pm 12,2$ & $36,5 \pm 2,5$ & $34,5 \pm 3,5$ \\
\hline 54 & $33,1 \pm 0,5$ & $54,8 \pm 11,0$ & $38,5 \pm 2,5$ & $33,0 \pm 2,0$ \\
\hline 55 & $35,8 \pm 2,6$ & $48,1 \pm 1,3$ & $36,5 \pm 2,5$ & $35,0 \pm 2,0$ \\
\hline 56 & $42,3 \pm 1,9$ & $59,4 \pm 7,0$ & $40,5 \pm 1,5$ & $34,0 \pm 3,0$ \\
\hline 57 & $43,8 \pm 0,2$ & $58,6 \pm 6,8$ & $45,5 \pm 4,5$ & $40,0 \pm 6,0$ \\
\hline 58 & $44,2 \pm 4,8$ & $54,1 \pm 2,7$ & $39,0 \pm 2,0$ & $35,5 \pm 2,5$ \\
\hline 59 & $47,3 \pm 2,7$ & $65,9 \pm 8,5$ & $42,5 \pm 4,5$ & $41,5 \pm 1,5$ \\
\hline 60 & $33,5 \pm 8,1$ & $60,1 \pm 9,3$ & $43,5 \pm 3,5$ & $40,5 \pm 2,5$ \\
\hline
\end{tabular}

${ }^{*} \mathrm{p}<0,05$, teste $\mathrm{t}$. 


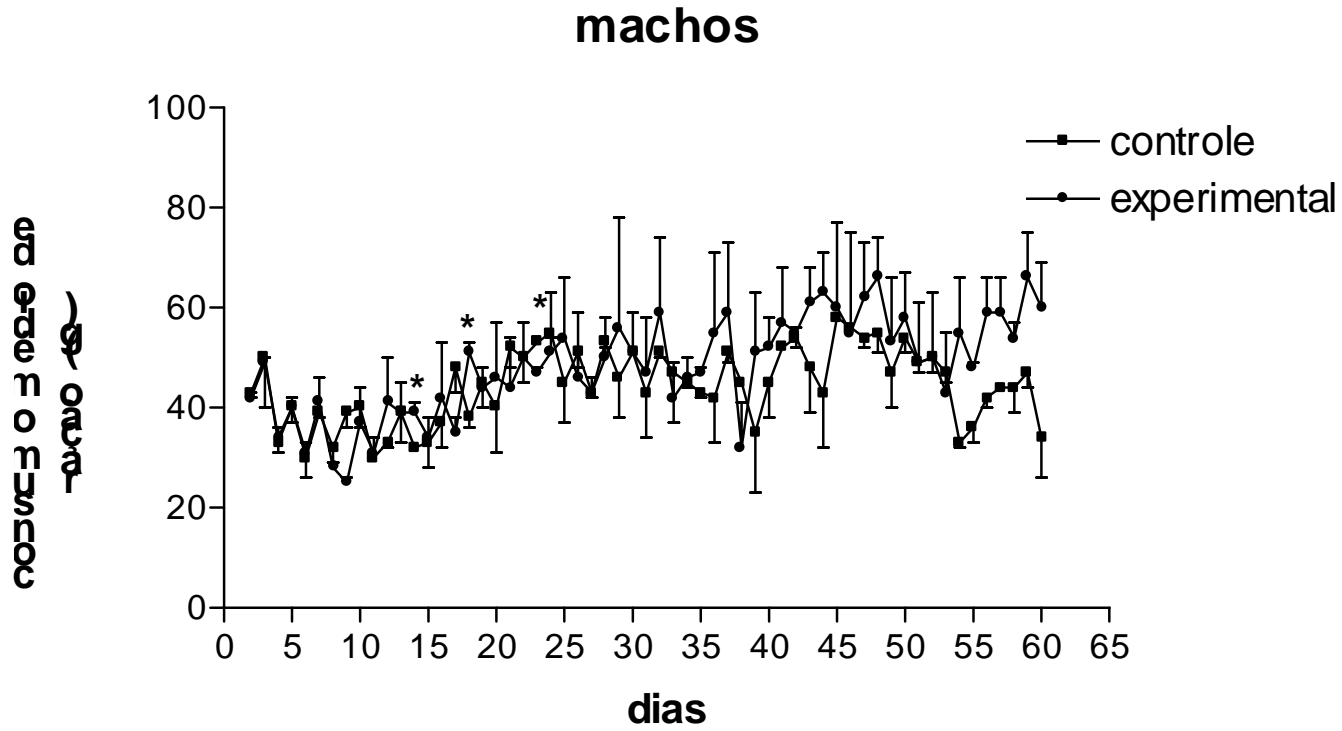

machos

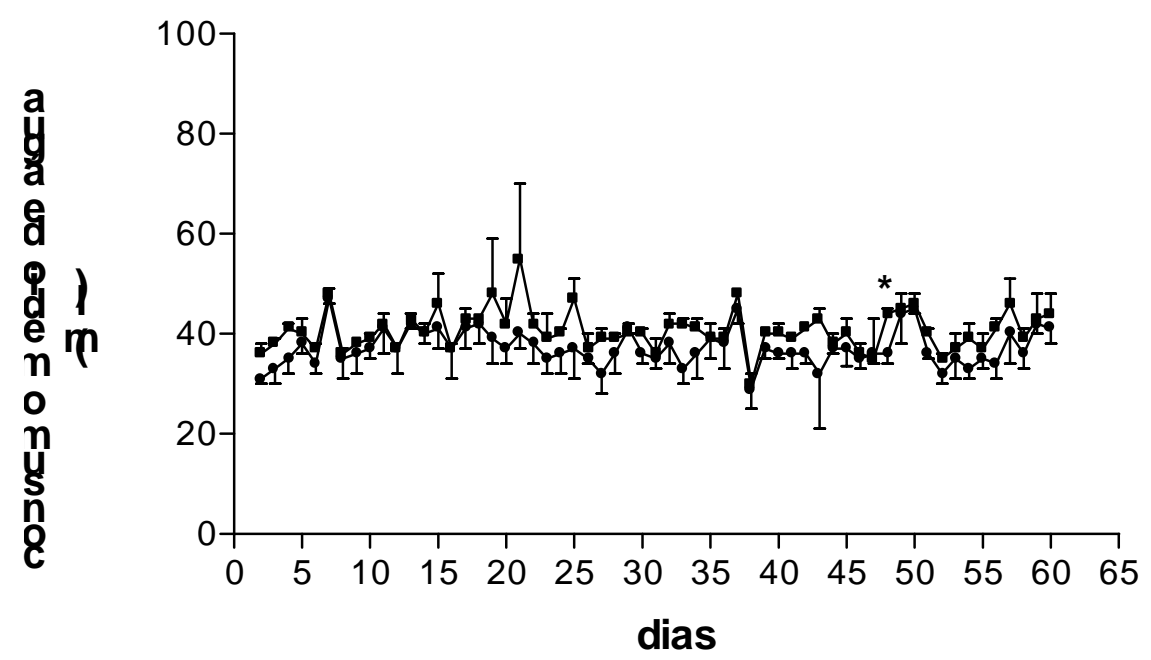

Figura 9. Consumo médio de ração e de água de ratos que receberam $3 \%$ de Solanum lycocarpum $(n=9)$ na ração ou apenas ração moída (controle: $n=10$ ). São apresentadas as médias e os respectivos erros padrões.

${ }^{*} p<0,05$, teste $t$. 
Tabela 8. Peso (em gramas) dos órgãos de ratos que receberam, por 60 dias, 3\% de Solanum lycocarpum na ração ou apenas ração moída (controle). São apresentadas as médias e os respectivos erros padrões.

\begin{tabular}{lcc}
\hline Órgão & Controle $(\mathrm{n}=10)$ & S. lycocarpum $(\mathrm{n}=9)$ \\
\hline Vesícula seminal & $1,160 \pm 0,049$ & $1,041 \pm 0,126$ \\
Adrenal direita & $0,026 \pm 0,002$ & $0,025 \pm 0,002$ \\
Adrenal esquerda & $0,029 \pm 0,002$ & $0,029 \pm 0,002$ \\
Testículo direito & $2,673 \pm 0,100$ & $2,676 \pm 0,076$ \\
Testículo esquerdo & $2,714 \pm 0,099$ & $2,641 \pm 0,080$ \\
Fígado & $14,226 \pm 0,673$ & $13,541 \pm 0,642$ \\
\hline p $>0,05$, teste t & &
\end{tabular}


Tabela 9. Valores de ALT, AST, albumina, creatinina, fosfatase alcalina e proteínas totais de ratos que receberam, por 60 dias, 3\% de Solanum lycocarpum na ração ou apenas ração moída (controle). São apresentadas as médias e os respectivos erros padrões.

\begin{tabular}{lcc}
\hline & Controle $(\mathrm{n}=10)$ & S. lycocarpum $(\mathrm{n}=9)$ \\
\hline ALT $(\mathrm{U} / \mathrm{l})$ & $48,189 \pm 7,180$ & $52,768 \pm 5,380$ \\
AST $(\mathrm{U} / \mathrm{l})$ & $118,56 \pm 6,702$ & $120,470 \pm 8,066$ \\
Albumina $(\mathrm{g} / \mathrm{dl})$ & $2,994 \pm 0,126$ & $3,281 \pm 0,056$ \\
Creatinina $(\mathrm{mg} / \mathrm{l})$ & $0,860 \pm 0,051$ & $0,831 \pm 0,042$ \\
Fosfatase alcalina $(\mathrm{U} / \mathrm{l})$ & $45,340 \pm 3,495$ & $46,057 \pm 3,640$ \\
Proteínas totais $(\mathrm{mmol} / \mathrm{l})$ & $16,639 \pm 0,690$ & $16,644 \pm 0,230$ \\
\hline p $>0,05$, teste t & &
\end{tabular}




\subsection{Experimento 3. Efeitos do consumo de S. lycocarpum durante a gestação.}

Foram utilizadas 30 ratas adultas nas quais foram realizados 0 controle do ciclo estral e acasalamento, conforme descrito nos ítens 3.3 .1 e 3.3.5. Após a detecção da prenhez os animais foram divididos em 3 grupos: um controle e dois experimentais. As ratas de um dos grupos experimentais receberam durante o período de pré-implantação, isto é, do dia 1 (dia da detecção da prenhez) ao $6^{0}$ dia de prenhez, a planta na dieta e após este período apenas a ração, conforme descrito no ítem 3.2. As ratas do outro grupo experimental receberam a dieta contendo a planta durante o período de organogênese, isto é, $6^{0}$ ao $16^{0}$ dia de gestação, sendo que durante os dias $1^{0}$ ao $5^{0}$ dia de gestação e a partir do $17^{0}$ dia de gestação receberam apenas a ração, conforme descrito no ítem 3.2. As ratas do grupo controle receberam durante todo o período de gestação apenas a ração.

Avaliou-se durante o período de gestação o consumo de água e ração e no $21^{\circ}$ dia de gestação todas as ratas foram submetidas a eutanásia em câmara saturada de éter etílico, procedendo-se, a seguir, a laparotomia para avaliação do desempenho reprodutivo materno aos 21 dias de gestação (conforme descrito no item 3.3.6) e a análise dos fetos (conforme descrito no item 3.3.7).

A Tab. 10 e a Fig. 10 mostram o consumo de ração de ratas que receberam durante o período de pré-implantação (dia 1 ao 6) ou de organogênese (dia 6 ao 16) ração contendo 3\% S. lycocarpum. Assim, nota- 
se aumento do consumo de ração no $9^{0}$ e no $14^{0}$ dia de gestação nas ratas do grupo pré-implantação, quando comparado com o consumo de ratas do grupo controle.

A Tab. 11 e a Fig. 11 mostram o consumo de água de ratas que receberam durante o período de pré-implantação (dia 1 ao 6) ou de organogênese (dia 6 ao 16) ração contendo 3\% S. lycocarpum. Assim, notase redução do consumo de água apenas no $4^{\circ}$ dia de gestação nas ratas do grupo pré-implantação, quando comparado com o consumo de ratas do grupo controle.

A Tab. 12 mostra os parâmetros do desempenho reprodutivo de ratas que receberam durante o período de pré-implantação (dia 1 ao 6) ou de organogênese (dia 6 ao 16) ração contendo 3\% de S. lycocarpum. Assim, nota-se que o número de fêmeas acasaladas com fetos vivos e com fetos mortos, os pesos maternos no $1^{\circ}$ e no $21^{\circ}$ dias de gestação, o ganho de peso (entre o $1^{\circ}$ e o $21^{\circ}$ dias de gestação, sem o útero gravídico), o número total de corpos lúteos, o número total de implantações, o número total de reabsorções pré-implantação, o número total de reabsorções pósimplantação, as porcentagens de perdas pré- e pós-implantação, o número total de filhotes, o número total de filhotes machos, a relação macho/fêmea por mãe, o peso médio da ninhada, peso de filhotes machos e o peso de filhotes fêmeas não mostraram diferenças significantes entre os grupos controle e experimentais. Por outro lado, a média de filhotes fêmeas do grupo cujas mães receberam ração contendo S. lycocarpum a 3\% durante a organogênese encontra-se aumentada em relação ao grupo controle. Além 
disso, neste mesmo grupo observa-se redução do peso da placenta em comparação ao grupo controle.

de filhotes do grupo controle (81 filhotes).

Ao exame visual, a prole de ratas expostas à S. lycocarpum, na proporção de 3\% na ração, durante o período de pré-implantação, apresentou uma fêmea com encurtamento de membros, que ao exame esquelético apresentou diminuição da ossificação da cabeça, maior espaço de fontanela, alterações de metacarpos e metatarsos, não houve fechamento de vértebras, costelas não estavam totalmente desenvolvidas e fusão de esternébrios.

A Tab. 13 mostra as malformações e/ou anomalias constatadas em pelo menos um feto quando procedeu-se o exame visceral destes animais cujas mães receberam durante o período de pré-implantação (dia 1 ao 6) ou de organogênese (dia 6 ao 16) ração contendo 3\% S. lycocarpum ou apenas a ração moída (grupo controle). Assim, nota-se que não foram observadas alterações significantes entre os grupos quanto a presença de dilatação dos ventrículos cerebrais, microcefalia, hemorragia de encéfalo, anoftalmia, dilatação dos seios nasais, ausência ou hemorragia de glândulas salivares, pontos de hemorragia no timo, dilatação ou hemorragia do coração, arco aórtico duplo, hipoplasia ou hemorragia de pulmões, pulmões com aspecto esponjoso, ausência ou hipoplasia das gônadas, dilatação da pelve renal, rins ectópicos, ausência de adrenais e hipoplasia de bexiga. Por outro lado, nota-se que houve aumento significante do número de fetos e ninhadas com hemorragia do bulbo olfatório e redução do número de ninhadas com 
hemorragia na musculatura no grupo cujas ratas receberam a planta misturada à ração no período de pré-implantação, quando comparado ao grupo controle.

A Tab. 14 mostra as malformações e/ou anomalias constatadas em pelo menos um feto quando procedeu-se o exame esquelético de animais cujas mães receberam durante o período de pré-implantação (dia 1 ao 6) ou de organogênese (dia 6 ao 16) ração contendo 3\% S. lycocarpum ou apenas ração moída (grupo controle). Assim, nota-se que não foram observadas alterações significantes entre os grupos quanto a redução da ossificação craniana, aumento ou redução do espaço entre os ossos parietal e frontal, ausência de metacarpo, agenesia de falanges e de vértebras caudais, costelas onduladas, agenesia de costelas e de esternébrios, ou destes últimos apresentando os tipos borboleta, rudimentar, bipartido e com alteração de forma. Porém, observa-se aumento significante no número de fetos apresentando esternébrios assimétricos no grupo que recebeu $S$. lycocarpum misturada à ração moída durante o período de organogênese, quando comparado ao grupo controle. 
Tabela 10. Consumo de ração (em gramas) de ratas que receberam durante o período de pré-implantação (dia 1 ao 6) ou de organogênese (dia 6 ao 16) 3\% de Solanum lycocarpum na ração ou apenas ração moída (controle). São apresentadas as médias e os respectivos erros padrões.

\begin{tabular}{cccc}
\hline Dia da gestação & $\begin{array}{c}\text { Controle } \\
(\mathrm{n}=10)\end{array}$ & $\begin{array}{c}\text { Pré-implantação } \\
(\mathrm{n}=10)\end{array}$ & $\begin{array}{c}\text { Organogênese } \\
(\mathrm{n}=10)\end{array}$ \\
\hline 2 & $25,34 \pm 3,80$ & $23,42 \pm 5,04$ & $24,30 \pm 2,93$ \\
3 & $25,04 \pm 2,68$ & $30,14 \pm 3,45$ & $23,44 \pm 2,28$ \\
4 & $22,02 \pm 2,24$ & $30,50 \pm 3,92$ & $24,46 \pm 2,43$ \\
5 & $22,56 \pm 1,71$ & $26,50 \pm 3,28$ & $21,70 \pm 1,58$ \\
6 & $26,06 \pm 1,59$ & $27,04 \pm 2,42$ & $21,71 \pm 1,33$ \\
7 & $23,60 \pm 1,82$ & $25,92 \pm 3,73$ & $20,15 \pm 1,59$ \\
8 & $26,60 \pm 1,72$ & $28,16 \pm 4,96$ & $22,04 \pm 2,15$ \\
9 & $23,70 \pm 2,64$ & $37,08 \pm 5,40^{\star}$ & $24,38 \pm 3,26$ \\
10 & $22,18 \pm 1,35$ & $22,57 \pm 3,28$ & $21,91 \pm 2,14$ \\
11 & $23,99 \pm 1,68$ & $25,09 \pm 1,99$ & $21,14 \pm 1,02$ \\
12 & $23,54 \pm 1,49$ & $28,70 \pm 3,51$ & $20,33 \pm 2,26$ \\
13 & $26,48 \pm 2,62$ & $35,63 \pm 4,59$ & $28,55 \pm 4,03$ \\
14 & $24,49 \pm 1,12$ & $35,83 \pm 5,45^{*}$ & $25,96 \pm 2,50$ \\
15 & $28,86 \pm 3,04$ & $28,15 \pm 3,76$ & $27,48 \pm 3,59$ \\
16 & $26,75 \pm 3,92$ & $26,60 \pm 2,33$ & $28,35 \pm 3,60$ \\
17 & $26,74 \pm 2,62$ & $26,27 \pm 2,28$ & $34,08 \pm 3,77$ \\
18 & $30,01 \pm 3,52$ & $29,91 \pm 3,07$ & $31,74 \pm 4,64$ \\
19 & $31,50 \pm 4,38$ & $25,79 \pm 1,23$ & $31,13 \pm 4,39$ \\
20 & $27,19 \pm 3,26$ & $24,66 \pm 2,79$ & $22,83 \pm 2,00$ \\
21 & $22,30 \pm 1,14$ & $24,17 \pm 2,29$ & $26,98 \pm 2,90$ \\
\hline
\end{tabular}

$p<0,05$, ANOVA seguida de Tukey-Kramer. 


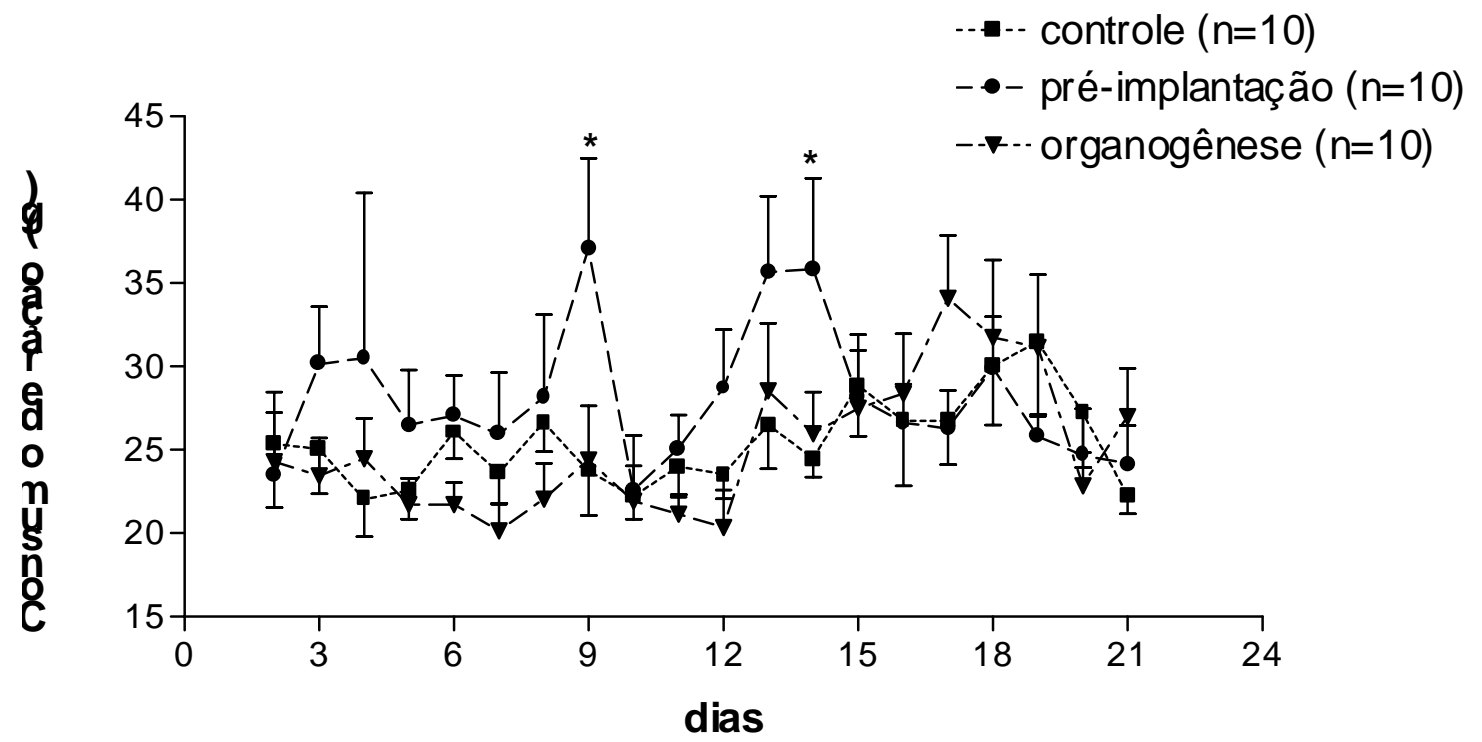

Figura 10. Consumo de ração (em gramas) de ratas que receberam durante o período de pré-implantação (dia 1 ao 6) ou de organogênese (dia 6 ao 16) 3\% de Solanum lycocarpum na ração ou apenas ração moída (controle). São apresentadas as médias e os respectivos erros padrões.

* $p<0,05$, ANOVA seguida de Tukey-Kramer. 
Tabela 11. Consumo de água $(\mathrm{em} \mathrm{ml}$ ) de ratas que receberam durante 0 período de pré-implantação (dia 1 ao 6) ou de organogênese (dia 6 ao 16) 3\% de Solanum lycocarpum na ração ou apenas ração moída (controle). São apresentadas as médias e os respectivos erros padrões.

\begin{tabular}{cccc|}
\hline Dia da gestação & $\begin{array}{c}\text { Controle } \\
(\mathrm{n}=10)\end{array}$ & $\begin{array}{c}\text { Pré-implantação } \\
(\mathrm{n}=10)\end{array}$ & $\begin{array}{c}\text { Organogênese } \\
(\mathrm{n}=10)\end{array}$ \\
\hline 2 & $29,20 \pm 3,42$ & $24,10 \pm 2,03$ & $30,90 \pm 1,27$ \\
3 & $39,00 \pm 3,25$ & $34,90 \pm 2,96$ & $34,10 \pm 2,18$ \\
4 & $45,00 \pm 3,50$ & $35,13 \pm 1,91^{*}$ & $46,90 \pm 1,94$ \\
5 & $42,67 \pm 4,27$ & $36,83 \pm 4,34$ & $44,89 \pm 2,11$ \\
6 & $46,70 \pm 2,71$ & $38,60 \pm 3,90$ & $46,90 \pm 5,31$ \\
7 & $43,80 \pm 1,71$ & $40,40 \pm 3,44$ & $43,00 \pm 3,17$ \\
8 & $40,90 \pm 2,00$ & $38,80 \pm 2,56$ & $42,30 \pm 1,84$ \\
9 & $41,90 \pm 3,66$ & $39,20 \pm 2,84$ & $38,40 \pm 1,95$ \\
10 & $45,60 \pm 3,30$ & $40,57 \pm 4,02$ & $41,60 \pm 1,33$ \\
11 & $45,00 \pm 5,25$ & $40,40 \pm 4,24$ & $43,13 \pm 1,92$ \\
12 & $46,89 \pm 4,73$ & $41,60 \pm 2,63$ & $45,00 \pm 4,15$ \\
13 & $46,44 \pm 3,54$ & $43,00 \pm 3,79$ & $40,11 \pm 2,81$ \\
14 & $49,14 \pm 3,99$ & $44,80 \pm 4,26$ & $47,50 \pm 4,75$ \\
15 & $45,00 \pm 2,64$ & $49,78 \pm 3,34$ & $48,30 \pm 5,95$ \\
16 & $48,60 \pm 1,52$ & $44,00 \pm 3,96$ & $46,50 \pm 4,08$ \\
17 & $51,80 \pm 2,57$ & $47,56 \pm 3,48$ & $49,00 \pm 3,80$ \\
18 & $51,90 \pm 3,19$ & $50,00 \pm 3,45$ & $55,80 \pm 6,13$ \\
19 & $54,50 \pm 3,19$ & $54,60 \pm 3,13$ & $55,11 \pm 7,14$ \\
20 & $50,40 \pm 3,02$ & $45,33 \pm 3,02$ & $45,56 \pm 3,54$ \\
21 & $48,00 \pm 2,42$ & $45,78 \pm 2,20$ & $43,78 \pm 2,88$ \\
\hline
\end{tabular}

* $p<0,05$, ANOVA seguida de Tukey-Kramer. 


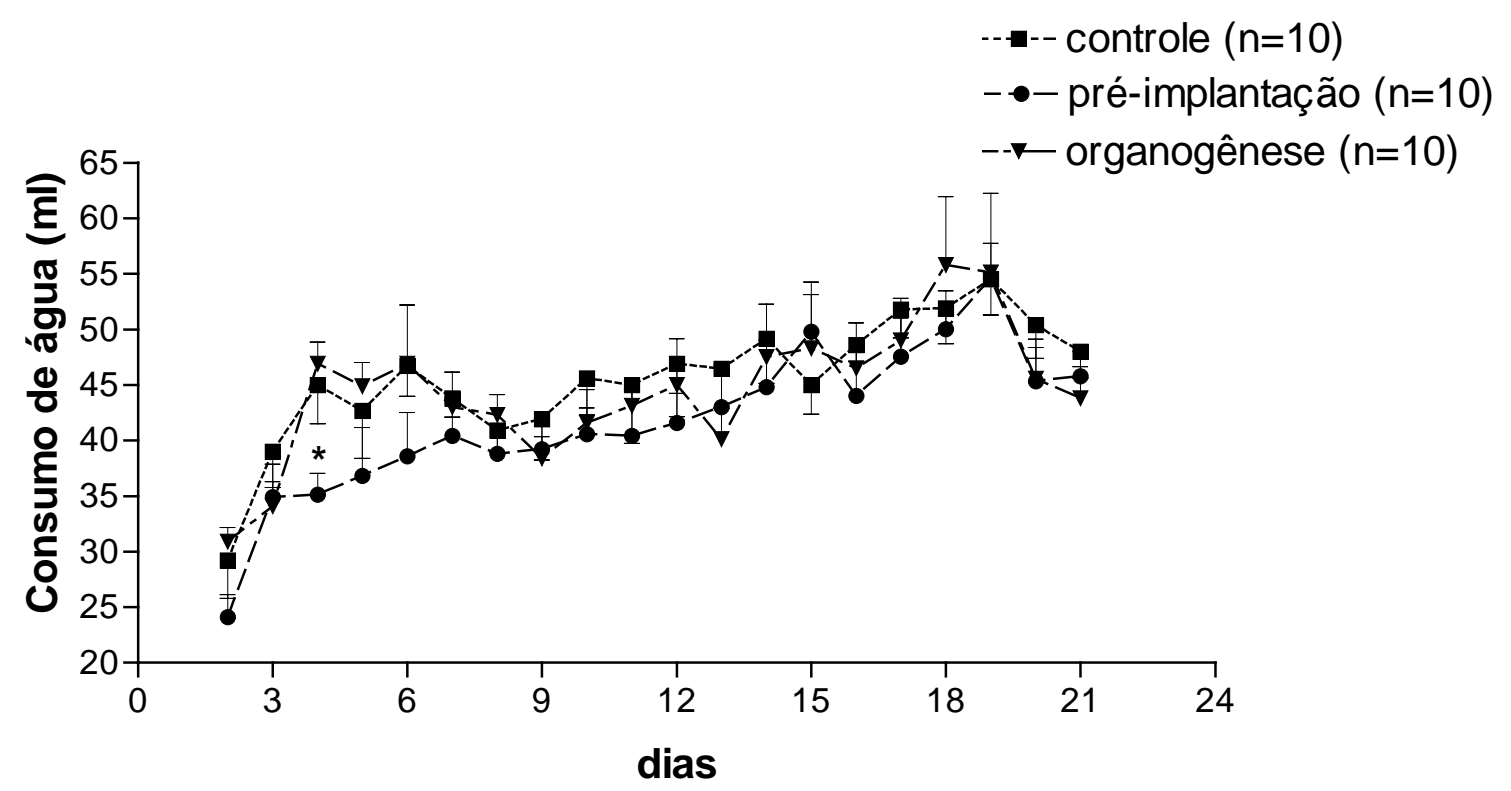

Figura 11. Consumo de água (em mililitros) de ratas que receberam durante o período de pré-implantação (dia 1 ao 6) ou de organogênese (dia 6 ao 16) 3\% de Solanum lycocarpum na ração ou apenas ração moída (controle). São apresentadas as médias e os respectivos erros padrões.

* $p<0,05$, ANOVA seguida de Tukey-Kramer. 
Tabela 12. Desempenho reprodutivo de ratas que receberam durante o período de pré-implantação (dia 0 ao 5) ou de organogênese (dia 6 ao 15) 3\% de Solanum lycocarpum na ração ou apenas ração moída (controle).

\begin{tabular}{|c|c|c|c|}
\hline Parâmetro & Controle & $\begin{array}{c}\text { Pré- } \\
\text { implantação }\end{array}$ & Organogênese \\
\hline $\begin{array}{c}N^{\circ} \text { de fêmeas acasaladas } \\
\text { - com fetos vivos } \\
\text { - com fetos mortos }\end{array}$ & $\begin{array}{c}10 \\
10 \\
0\end{array}$ & $\begin{array}{c}10 \\
10 \\
0\end{array}$ & $\begin{array}{c}10 \\
10 \\
0\end{array}$ \\
\hline $\begin{array}{l}\text { Peso materno no } 1^{0} \text { dia de } \\
\text { gestação }(\mathrm{g})^{a}\end{array}$ & $217,14 \pm 8,51$ & $220,19 \pm 6,36$ & $219,61 \pm 6,88$ \\
\hline $\begin{array}{l}\text { Peso materno no } 21^{\circ} \text { de } \\
\text { gestação sem } 0 \\
\text { gravídico }(\mathrm{g})^{\mathrm{a}}\end{array}$ & $251,89 \pm 10,24$ & $251,96 \pm 7,10$ & $253,21 \pm 13,20$ \\
\hline $\begin{array}{l}\text { Ganho de peso materno (dia } 1 \\
\text { ao } 21 \text { ) sem o útero gravídico } \\
\text { (g) a }\end{array}$ & $34,75 \pm 3,75$ & $31,77 \pm 2,21$ & $33,60 \pm 7,03$ \\
\hline 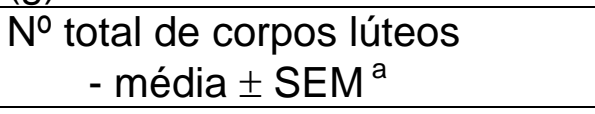 & $\begin{array}{c}114 \\
11,40 \pm 0,48 \\
\end{array}$ & $\begin{array}{c}114 \\
11,40 \pm 0,43\end{array}$ & $\begin{array}{c}120 \\
12,00 \pm 0,73\end{array}$ \\
\hline $\begin{array}{c}\mathrm{N}^{0} \text { total de implantação } \\
-(\text { média } \pm \text { SEM })^{a}\end{array}$ & $\begin{array}{c}90 \\
9,00 \pm 0,82 \\
\end{array}$ & $\begin{array}{c}97 \\
9,70 \pm 0,63 \\
\end{array}$ & $\begin{array}{c}112 \\
11,20 \pm 0,53 \\
\end{array}$ \\
\hline $\begin{array}{l}\text { No total de reabsorções pré- } \\
\text { implantação } \\
\quad-\quad \text { média } \pm S E M^{a}\end{array}$ & $0,90 \pm 0,59$ & $1,40 \pm 0,65$ & $0,70 \pm 0,42$ \\
\hline $\begin{array}{l}\text { No total de reabsorções pós- } \\
\text { implantação } \\
\quad-\quad \text { média } \pm S E \mathrm{SM}^{\mathrm{a}}\end{array}$ & $\begin{array}{c}8 \\
0,80 \pm 0,49\end{array}$ & $0,80 \pm 0,29$ & $\begin{array}{c}5 \\
0,50 \pm 0,31\end{array}$ \\
\hline$\%$ de perda pré-implantação ${ }^{b}$ & 19,7 & 14,5 & 5,6 \\
\hline$\%$ de perda pós-implantação ${ }^{b}$ & 9,3 & 8,2 & 4,4 \\
\hline $\begin{array}{c}N^{0} \text { total de filhotes vivos } \\
-\quad \text { média } \pm \text { SEM }^{\text {a }}\end{array}$ & $\begin{array}{c}81 \\
8,10 \pm 0,89\end{array}$ & $\begin{array}{c}90 \\
9,00 \pm 0,86\end{array}$ & $\begin{array}{c}107 \\
10,7 \pm 0,60\end{array}$ \\
\hline $\begin{array}{l}\mathrm{N}^{\mathrm{o}} \text { total de filhotes machos } \\
-{\text { média } \pm S E M^{\mathrm{a}}}^{\mathrm{a}}\end{array}$ & $\begin{array}{c}48 \\
4,80 \pm 0,57\end{array}$ & $\begin{array}{c}50 \\
5,00 \pm 0,87\end{array}$ & $\begin{array}{c}52 \\
5,2 \pm 0,68\end{array}$ \\
\hline 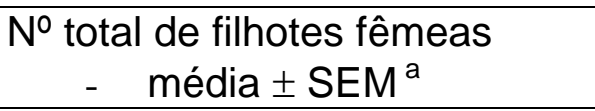 & $\begin{array}{c}33 \\
3,30 \pm 0,67\end{array}$ & $\begin{array}{c}40 \\
4,00 \pm 0,47\end{array}$ & $\begin{array}{c}55 \\
5,50 \pm 0,43^{*}\end{array}$ \\
\hline $\begin{array}{l}\text { Relação macho/fêmea } \\
\text { mãe (mediana e limites) }\end{array}$ & $\begin{array}{c}1,3 \\
(0,6-5,0)\end{array}$ & $\begin{array}{c}1,5 \\
(0,2-4,0)\end{array}$ & $\begin{array}{c}1,0 \\
(0,1-2,7)\end{array}$ \\
\hline Peso médio da ninhada $(\mathrm{g})^{\mathrm{a}}$ & $3,84 \pm 0,14$ & $3,65 \pm 0,14$ & $3,67 \pm 0,08$ \\
\hline Peso dos filhotes machos $(\mathrm{g})^{a}$ & $3,93 \pm 0,06$ & $3,85 \pm 0,07$ & $3,85 \pm 0,04$ \\
\hline Peso dos filhotes fêmeas $(\mathrm{g})^{a}$ & $3,54 \pm 0,07$ & $3,59 \pm 0,07$ & $3,49 \pm 0,05$ \\
\hline Peso da placenta $(\mathrm{g})^{\mathrm{a}}$ & $0,52 \pm 0,03$ & $0,52 \pm 0,01$ & $0,40 \pm 0,02^{*}$ \\
\hline
\end{tabular}

${ }^{\text {a }}$ ANOVA; ${ }^{\text {b }}$ Kruskal-Wallis

${ }^{*} \mathrm{p}<0,05$, ANOVA seguida de Dunnett 
Tabela 13. Exame visceral de fetos cujas ratas receberam durante o período de pré-implantação (dia 0 ao 5) ou de organogênese (dia 6 ao 15) 3\% de Solanum lycocarpum na ração ou apenas ração moída (controle) (cont.)

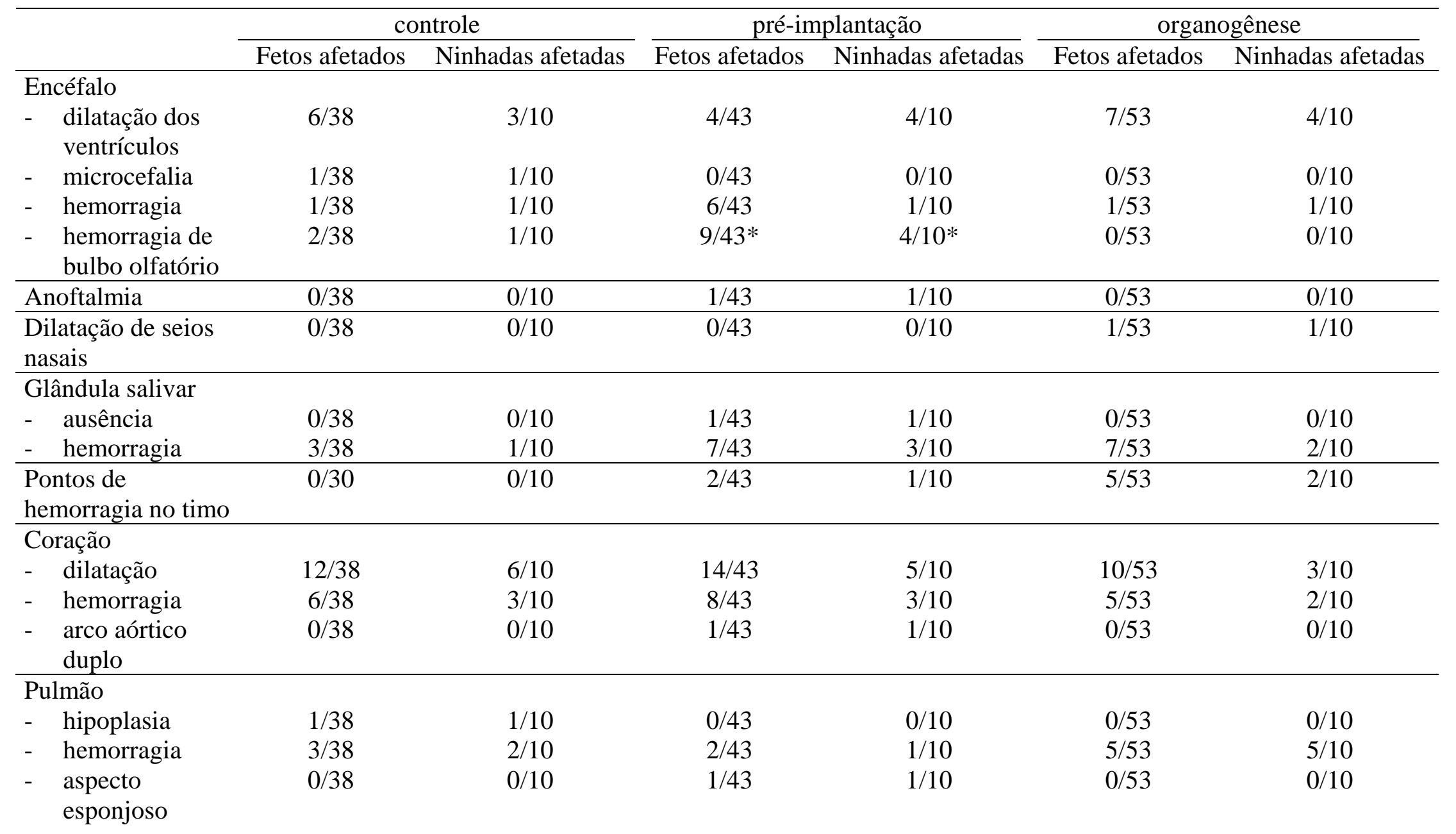


Tabela 13. Exame visceral de fetos cujas ratas receberam durante o período de pré-implantação (dia 0 ao 5 ) ou de organogênese (dia 6 ao 15) 3\% de Solanum lycocarpum na ração ou apenas ração moída (controle) (cont.)

\begin{tabular}{|c|c|c|c|c|c|c|}
\hline & \multicolumn{2}{|c|}{ controle } & \multicolumn{2}{|c|}{ pré-implantação } & \multicolumn{2}{|c|}{ organogênese } \\
\hline & Fetos afetados & Ninhadas afetadas & Fetos afetados & Ninhadas afetadas & Fetos afetados & Ninhadas afetadas \\
\hline Gônadas & & & & & & \\
\hline - ausência & $0 / 38$ & $0 / 10$ & $0 / 43$ & $0 / 10$ & $1 / 53$ & $1 / 10$ \\
\hline - hipoplasia & $1 / 38$ & $1 / 10$ & $2 / 43$ & $1 / 10$ & $2 / 53$ & $2 / 10$ \\
\hline Rim & & & & & & \\
\hline $\begin{array}{l}\text { - Dilatação da } \\
\text { pelve }\end{array}$ & $1 / 38$ & $1 / 10$ & $5 / 43$ & $3 / 10$ & $4 / 53$ & $3 / 10$ \\
\hline - Ectopia & $9 / 38$ & $6 / 10$ & $4 / 43$ & $4 / 10$ & $15 / 53$ & $5 / 10$ \\
\hline $\begin{array}{l}\text { Ausência de } \\
\text { adrenal }\end{array}$ & $0 / 38$ & $0 / 10$ & $2 / 43$ & $1 / 10$ & $0 / 53$ & $0 / 10$ \\
\hline $\begin{array}{l}\text { Hipoplasia de } \\
\text { bexiga }\end{array}$ & $0 / 38$ & $0 / 10$ & $3 / 43$ & $2 / 10$ & $1 / 53$ & $1 / 10$ \\
\hline $\begin{array}{l}\text { Pontos de } \\
\text { hemorragia na } \\
\text { musculatura }\end{array}$ & $14 / 38$ & $8 / 10$ & $9 / 43$ & $2 / 10^{*}$ & $14 / 53$ & $6 / 10$ \\
\hline
\end{tabular}

* $\mathrm{p}<0,05$ tese Qui-quadrado. 
Tabela 14. Exame esquelético de fetos cujas ratas receberam durante o período de pré-implantação (dia 0 ao 5) ou de organogênese (dia 6 ao 15) 3\% de Solanum lycocarpum na ração ou apenas ração moída (controle).

\begin{tabular}{|c|c|c|c|c|c|c|}
\hline & \multicolumn{2}{|c|}{ controle } & \multicolumn{2}{|c|}{ pré-implantação } & \multicolumn{2}{|c|}{ organogênese } \\
\hline & Fetos afetados & Ninhadas afetadas & Fetos afetados & Ninhadas afetadas & Fetos afetados & Ninhadas afetadas \\
\hline \multicolumn{7}{|l|}{ Cabeça } \\
\hline - $\quad \downarrow$ ossificação & $0 / 42$ & $0 / 10$ & $2 / 43$ & $2 / 10$ & $0 / 52$ & $0 / 10$ \\
\hline - $\quad \uparrow$ espaço entre & $2 / 42$ & $2 / 10$ & $3 / 43$ & $2 / 10$ & $6 / 52$ & $3 / 10$ \\
\hline $\begin{array}{l}\text { parietal/frontal } \\
\downarrow \text { - espaço entre } \\
\text { parietal/frontal }\end{array}$ & $1 / 42$ & $1 / 10$ & $4 / 43$ & $3 / 10$ & $1 / 52$ & $1 / 10$ \\
\hline $\begin{array}{l}\text { Ausência de } \\
\text { metacarpo }\end{array}$ & $0 / 42$ & $0 / 10$ & $1 / 43$ & $1 / 10$ & $0 / 52$ & $0 / 10$ \\
\hline $\begin{array}{l}\text { Agenesia de } \\
\text { falanges }\end{array}$ & $0 / 42$ & $0 / 10$ & $1 / 43$ & $1 / 10$ & $0 / 52$ & $0 / 10$ \\
\hline $\begin{array}{l}\text { Agenesia de } \\
\text { vértebras caudais }\end{array}$ & $0 / 42$ & $0 / 10$ & $0 / 43$ & $0 / 10$ & $1 / 52$ & $1 / 10$ \\
\hline \multicolumn{7}{|l|}{ Costelas } \\
\hline - agenesia & $1 / 43$ & $1 / 10$ & $0 / 43$ & $0 / 10$ & $0 / 52$ & $0 / 10$ \\
\hline - onduladas & $0 / 43$ & $0 / 10$ & $2 / 43$ & $1 / 10$ & $0 / 52$ & $0 / 10$ \\
\hline \multicolumn{7}{|l|}{ Esternébrio } \\
\hline - $\quad$ menos de 6 & $11 / 42$ & $4 / 10$ & $12 / 43$ & $5 / 10$ & $11 / 52$ & $5 / 10$ \\
\hline - borboleta & $14 / 42$ & $7 / 10$ & $21 / 43$ & $8 / 10$ & $21 / 52$ & $10 / 10$ \\
\hline - rudimentar & $11 / 42$ & $6 / 10$ & $11 / 43$ & $7 / 10$ & $15 / 52$ & $8 / 10$ \\
\hline - $\quad$ bipartido & $0 / 42$ & $0 / 10$ & $0 / 43$ & $0 / 10$ & $2 / 52$ & $2 / 10$ \\
\hline - assimétrico & $11 / 42$ & $7 / 10$ & $16 / 43$ & $7 / 10$ & $29 / 52 *$ & $10 / 10$ \\
\hline $\begin{array}{l}\text { - } \begin{array}{l}\text { alteração de } \\
\text { forma }\end{array}\end{array}$ & $9 / 42$ & $6 / 10$ & $9 / 43$ & $5 / 10$ & $15 / 52$ & $6 / 10$ \\
\hline
\end{tabular}

$\downarrow$ diminuição; $\uparrow$ aumento

* $\mathrm{p}<0,05$ tese Qui-quadrado. 


\section{DISCUSSÃO}

Os efeitos tóxicos de uma substância química no organismo de um animal podem ser avaliados pelo exame físico diário, peso corporal e de órgãos, avaliação do consumo de água e de comida, exames hematológicos, provas bioquímicas da função de órgãos/tecidos, estudos anatopatológicos, dentre outros (STEVENS e GALLO, 1989). No presente trabalho estes parâmetros foram usados para avaliar a toxicidade da S. lycocarpum em ratos, machos e fêmeas, adultos.

O peso corporal é um dos parâmetros mais empregados em avaliações toxicológicas para indicar o aparecimento, muitas vezes precoce, de efeitos tóxicos de uma determinada substância no organismo animal (STEVENS e GALLO, 1989). No presente estudo, a administração dos frutos de S. lycocarpum à $3 \%$ na ração por 37 dias reduziu o peso corporal das fêmeas em vários dias de observação, embora não tenha alterado o ganho de peso neste período, e provocou redução no consumo de água em alguns dias de exposição à planta, não alterando o consumo de ração. Quanto aos machos que receberam a planta por 60 dias na ração pouquíssimas alterações foram observadas nestes parâmetros (peso, ganho de peso e consumo de água e ração). Estes achados sugerem que a mistura de $3 \%$ de S. lycocarpum é suficientemente palatável para permitir o consumo normal de alimento e para manter o crescimento adequado, uma vez que nenhuma redução de ganho de peso corporal e do consumo de comida foi observada, tanto em machos, como em fêmeas. Por outro lado, os dados indicam a ocorrência de um efeito tóxico sutil da planta em fêmeas, caracterizado por 
redução significante do peso corpóreo e consumo de água em alguns dias de observação.

Deve ser salientado que neste trabalho optou-se por uma exposição prolongada à planta para melhor se aproximar as condições de exposição na qual os animais de produção (caprinos, ovinos, bovinos) poderiam estar submetidos em condições naturais no campo. Além disto, os protocolos experimentais empregados para estudos de toxidade da reprodução recomendam estes períodos de exposição respectivamente para fêmeas e machos (MANSON e KANG, 1989; ZENICK e CLEGG, 1989).

SÁ et al. (2000) num experimento no qual administrou por um período de tempo bastante inferior ao nosso, isto é, 5 dias, o polvilho da $S$. lycocarpum diluído na água, duas vezes ao dia, por gavage, a ratos e camundongos machos, também não observou diferenças significantes no peso e ganho de peso destes animais.

FRIEDMAN et al. (1996) trabalhando com vários alcalóides encontrados em plantas como batata, tomate e berinjela, observaram redução no peso de camundongos fêmeas adultas tratadas com solasonina (encontrada também na S. lycocarpum), solanidina e solanina, por 7 ou 14 dias. Estes autores relatam também que os machos apresentam redução de ganho de peso e consumo de ração, enquanto as fêmeas mostram apenas redução no consumo de ração quando tratados com solasodina, princípio ativo também presente na $S$. lycocarpum. Estes achados sugerem diferenças na resposta aos efeitos destas substâncias relacionadas ao sexo, como aquelas observadas em nosso experimento. 
Como já citado anteriormente, a S. Iycocarpum possui glicoalcalóides esteroidais, que foram caracterizados como sendo a solamargina e a solasonina, cuja aglicona é a solasodina (MOTIDOME et al., 1970; HARAGUCHI et al., 1978), assim como um alcalóide com configuração estereospecífica para a síntese de hormônios esteróides (KERBER, 1993). Por outro lado, substâncias estrogênicas não-esteroidais encontradas em plantas, chamadas fitoestrógenos, tem despertado o interesse em Medicina Humana, onde são indicados principalmente na terapia de reposição hormonal de mulheres, e em Medicina Veterinária devido aos transtornos causados na reprodução, em particular, de bovinos.

Os fitoestrógenos e também as micotoxinas estrogênicas estão presentes largamente na natureza, podendo causar seus efeitos tóxicos sobre o sistema reprodutor de mamíferos expostos em condições naturais e, recentemente, seus efeitos como desreguladores endócrinos tem sido estudados (KELCE e GRAY, 1997). Assim, ilustrando alguns destes achados, LABOV, em 1977, comenta que durante a Segunda Guerra Mundial os holandeses consumiam grande quantidade de bulbos de tulipas estrogênicas, os quais, em mulheres, causavam sinais evidentes de estrogenismo, incluindo sangramento uterino e outras anomalias do ciclo menstrual.

Em Medicina Veterinária observou-se que os animais também podem ser afetados pelo consumo de plantas e micotoxinas estrogênicas. Assim, soja contendo isoflavonas totais em quantidade superior a $0,25 \%$ pode induzir sinais de estrogenicidade em suínos e a presença de trevo em 
pastagens contendo formononetina causa problemas de fertilidade em ovinos (KELCE e GRAY, 1997). No mesmo sentido, a micotoxina zearalenona (que liga-se ao receptor de estrógeno e ativa a transcrição de genes dependentes de estrógeno) causa hipertrofia do miométrio, cornificação vaginal persistente e redução do tamanho do ovário devido a falta de corpos lúteos. O consumo de alimentos contaminados com Fusarium roseum (fungo que produz a zearalenona) pode prejudicar a fertilidade das vacas e causar hiperestrogenismo em suínos e perus (ADAMS, 1989).

No Brasil, PIMENTEL et al. (1977) relataram hiperestrogenismo causado por fitoestrógenos da pastagem, no Rio Grande do Sul. Estes autores estudaram um rebanho de treze novilhas da raça holandesa, com 20 a 22 meses de idade, submetidas a um experimento em que se usava pastagem artificial composta de 95\% de "trevo-subterrâneo" (Trifolium subterraneum L. var. Yarloop) e 5\% de "azevém" (Loloium multiflorum Lamk.), com o objetivo de fazer com que os animais atingissem $350 \mathrm{~kg}$ aos 24 meses de idade. Após 4 meses nesse regime, foi solicitado o exame ginecológico, por se suspeitar de uma possível prenhez, em função do aumento de tamanho da glândula mamária e da vulva de dois animais. Das 13 novilhas submetidas a esse exame, seis $(46,1 \%)$ apresentaram cistos foliculares nos ovários, dez (76,9\%) turgidez uterina semelhante à do estro e oito $(56,2 \%)$ desenvolvimento da glândula mamária com secreção de aspecto lácteo. Todas as novilhas apresentaram hiperemia da mucosa vaginal, dilatação do canal cervical e abundante secreção mucosa na 
cavidade vaginal. Estes achados foram atribuídos a presença de fitoestrógenos da pastagem.

Sabe-se que os fitoestrógenos se ligam aos mesmos receptores intracelulares nos quais se liga o estradiol, porém com uma afinidade muito menor e produzem respostas fisiológicas similares, incluindo hipertrofia das glândulas acessórias nos machos e efeitos antigonadotrópicos no eixo hipotalâmico-pituitária e níveis de hormônios gonadais alterados em mamíferos de ambos os sexos (STOB, 1983).

No presente trabalho não foi constada nenhuma alteração no ciclo estral das ratas que receberam a S. lycocarpum na ração, porém observouse redução do peso dos cornos uterinos. Além disso, ao exame macroscópico das vísceras, uma das fêmeas do grupo experimental apresentou cistos foliculares, os quais foram observados também no estudo histopatológico em um número maior de fêmeas. Os achados anatomopatológicos revelaram, ainda, maior freqüência de hiperplasia do epitélio endometrial nas fêmeas do grupo experimental. Estes achados sugerem que a planta possa ter exercido algum desequilíbrio hormonal no sistema reprodutor destas fêmeas.

Efeitos tóxicos de plantas são analisados monitorizando-se alterações nos pesos corpóreo e de órgãos dos animais. No sistema reprodutivo de machos, reduções nos pesos das gônadas, epidídimos e órgãos sexuais acessórios são considerados critérios para a caracterização de agentes tóxicos que podem causar problemas de fertilidade no sujeito tratado (CHANG et al., 1990; MONONAYAGI, 1989). 
Estudos anteriores em camundongos e ratos machos tratados com suspensão aquosa do polvilho de lobeira em doses duas ou quatro vezes maiores que a terapêutica, duas vezes ao dia durante cinco dias, não causaram alterações no ganho de peso e no peso corpóreo dos animais. $\mathrm{O}$ tratamento reduziu o peso da próstata ventral, vesícula seminal e da glândula pituitária de camundongos, porém não alterou a produção de gametas levando à conclusão que a administração de $S$. lycocarpum neste protocolo não causa efeitos tóxicos sobre o sistema reprodutivo de ratos e em camundongos machos parece exercer um efeito antiandrogênico (SÁ et al., 2000).

Em nosso trabalho também não foram observados efeitos tóxicos sobre o sistema reprodutor de ratos machos, pois não foram observadas diferenças nos pesos dos testículos e vesícula seminal.

Avaliações da bioquímica sangüínea de machos e fêmeas tratados com S. lycocarpum também foram realizadas. Assim, as enzimas séricas clássicas como fosfatase alcalina, alanina aminotransferase e aspartato aminotransferase, bem como, creatinina e proteínas totais foram medidas.

Aspartato e alanina aminotransferases estão elevadas após danos teciduais, quando as enzimas celulares são liberadas das células para a corrente sangüínea. Aspartato aminotransferase é encontrada em níveis constitutivos altos no coração e no fígado, enquanto que, alanina aminotransferase é mais ativa no fígado. Creatinina é encontrada no coração, musculatura esquelética, cérebro e testículos, mas não no fígado. Níveis elevados são encontrados em desordens musculares, infarto do 
miocárdio, e desordens pulmonares. A fosfatase alcalina é encontrada na maioria dos tecidos, incluindo, ossos, fígado e rim. Elevações são vistas após a alimentação e atividade osteoblástica, prejuízo da função hepática, e obstrução do fluxo biliar; depressões são encontradas na desnutrição.

FRIEDMAN em 1992 observou que em camundongos o consumo de solasodina a $3,8 \mathrm{mmol} / \mathrm{kg}$ durante 14 dias causou hepatomegalia acompanhada por aumento de atividade de quatro enzimas hepáticas: fosfatase alcalina sérica, glutamato-oxaloacetato transaminase, glutamatopiruvato transaminase e $\mathrm{N}$-demetilase. Exames histológicos do tecido desses camundongos revelaram a presença de colangio-hepatite e dilatação/degeneração de glândulas gástricas. Porém um tratamento com solasodina por 14 dias seguido de tratamento com dieta livre do alcalóide por mais 14 dias fez com que o peso do fígado retornasse a valores próximos aos do grupo controle, indicando um efeito reversível sobre o fígado de camundongos e não uma lesão permanente (FRIEDMAN et al., 1996). Ainda, camundongos tratados com $\alpha$-chaconina e $\alpha$-solanina apresentaram redução significante do peso do fígado, efeitos que sugerem a ocorrência de hepatotoxicidade (FRIEDMAN, 1996).

Por ser o principal órgão metabolizador e detoxificador do organismo, o fígado está sujeito a danos causados por uma enorme gama de substâncias químicas. Da mesma forma, vários agentes podem causar prejuízos aos rins, principais órgãos excretores (COLTRAN et al., 1994).

No presente trabalho, foi observada redução do peso do fígado e os achados anatomopatológicos que revelaram aumento das freqüências de 
proliferação de ductos biliares, congestão hepática e renal em fêmeas expostas prolongadamente à $S$. Iycocarpum, sugerindo um efeito hepatotóxico e nefrotóxico que pode ser causado pelos alcalóides presentes na planta. Por outro lado, não foram observados efeitos na avaliação bioquímica tanto das fêmeas quanto dos machos. É possível que a este nível de intoxicação os danos aos órgãos não estejam comprometendo suas funções.

Os dados presentes mostram diferenças relacionadas ao sexo na toxicidade da S. lycocarpum, já que apenas as ratas apresentaram redução dos pesos do fígado e dos cornos uterinos e alterações ao exame anatomopatológico. Assim, outros estudos devem ser conduzidos para melhor investigar a toxicidade nas fêmeas e outros efeitos tóxicos de níveis maiores de exposição a esta planta.

O desenvolvimento embriológico e fetal consiste num desenrolar contínuo de mudanças e variações complexas e pode ser dividido em diferentes períodos. Assim, o período de implantação inicia-se após a fecundação, que é marcada pela anfimixia, ou seja, a fusão dos núcleos do óvulo e do espermatozóide; a seguir, o ovo se divide várias vezes, atingindo o estágio de blástula. Esta fase é chamada de segmentação, que se segue pelo implante do blastocisto no útero. Neste período, qualquer interferência produzida por um substância química leva à embrioletalidade, sendo muito rara a ocorrência de teratogênese (BERNARDI, 1999).

O período de organogênese é marcado por uma série de processos definidos seqüencialmente, que abrangem desde a proliferação, 
diferenciação e migração celular até a organogênese preopriamente dita, que consiste na formação de órgãos rudimentares. Agentes tóxicos, quando administrados às mães neste período, podem levar à teratogênese, se a lesão for compatível com a vida do animal, ou à embrioletalidade, caso não seja. Cada um dos sistemas em formação apresenta um período crítico particular, no qual ele é mais suscetível ao agente, quanto maior for o período crítico de um determinado sistema, tanto mais suscetível este será aos efeitos de um determinado agente. Por este motivo, nos testes de teratogênese, são sempre estudadas as possíveis anomalias ósseas dos animais, pois o período de organogênese do esqueleto é bastante longo (BERNARDI, 1999).

O termo teratogênese designa as malformações por agentes patológicos, químicos e ambientais durante o período de desenvolvimento dos órgãos de um animal, podendo ser de natureza estrutural e/ou funcional, ou seja, podem manifestar-se por um defeito físico ou bioquímico. Fato importante é que um agente teratogênico não gera uma determinada anomalia, mas aumenta a freqüência com que esta ocorre (BERNARDI, 1999).

Agentes tóxicos presentes no alimento e desequilíbrios de nutrientes específicos na dieta podem alterar as concentrações hormonais maternas e afetar a composição das secreções do oviduto e do útero o que resulta em diminuição da sobrevivência embrionária ou, em circunstâncias menos severas, alterações de crescimento e desenvolvimento (McEVOY et al., 2001). 
Neste sentido, JAMES et al. (1992) e PANTER et al. (1992) listaram plantas tóxicas encontradas no oeste dos Estados Unidos da América que são conhecidas pelos seus efeitos deletérios sobre a reprodução. Destas, uma planta comumente encontrada nas regiões úmidas, a Veratrum californicum, é um excelente exemplo de toxicidade durante um curto, porém crítico, período de desenvolvimento quando o embrião é particularmente vulnerável aos alcalóides esteroidais ciclopamina, cicloposina e jervina. Assim, ovelhas que consumiram a planta no décimo quarto dia de gestação apresentaram elevada mortalidade embrionária causada principalmente por defeitos do tubo neural que resulta em anormalidade facial ciclópica letal (BINNS et al., 1965). A exposição a esta planta entre o décimo nono e o vigésimo primeiro dias de gestação resulta em mortalidade embrionária, enquanto defeitos de membros envolvendo encurtamento do metacarpo, metatarso e tíbia resulta da esposição entre os dias gestacionais 27 e 32 . A esposição entre os dias 31 e 33 de gestação causa defeitos na traquéia, colapso traqueal e morte neonatal causada por asfixia (PANTER et al., 1992). A susceptibilidade a estas toxinas não está restrita às ovelhas; caprinos e bovinos também são vulneráveis e expressam efeitos específicos dependendo do estágio de gestação similares àqueles observados em ovinos. KEELER (1975), observou que os fetos de hamster são também muito vulneráveis aos efeitos teratogênicos tanto da ciclopamina quanto da jervina, que administradas no sétimo dia de gestação, induzem várias deformidades na cabeça. No mesmo trabalho, notou-se que uma linhagem 
de ratos foi susceptível à ciclopamina, mas não à jervina, enquanto camundongos Swiss Webster são resistentes a ambas toxinas.

Forragens estrogênicas fornecem outros exemplos de substâncias presentes em plantas que podem prejudicar a função ovariana, reduzir a concepção e aumentar a mortalidade embrionária. De acordo com ADAMS (1995) aproximadamente 4 milhões de ovelhas no oeste da Austrália sofrem de infertilidade subclínica permanente como resultado da exposição às plantas estrogênicas. Apesar de algumas plantas, como a alfafa (Medicago sativa), que contribuem com o problema possuírem quantidades baixas de fitoestrógenos, elas respondem ao ataque de fungos produzindo compostos estrogênicos como o coumestrol e o sativol. Em outros casos, como com o trevo vermelho, no qual o precurssor de estrógeno é a isoflavona fomononetina, a conservação da forragem como feno ou silagem aumentam a concentração do presursor que é, subseqüentemente, convertido no interior do rúmen ao fitoestrógeno equol (McEVOY et al., 2001).

As micotoxinas (aflatoxinas, zearalenona, deoxinivalenol, ocratoxina e ergot) produzidas por fungos possuem efeitos adversos no estabelecimento da gestação de suínos. Por exemplo, zearalenona e deoxinivalenol, produzidos pelo Fusarium roseum, exercem seus efeitos deletérios sobre o desenvolvimento embrionário durante o estreito período crítico entre o $7^{0}$ e 0 10ํ dias após o acasalamento (DIEKMAN e GREEN, 1992; LONG et al., 1992). Concentrações reduzidas (5 a 10 ppm) de zearalenona antes da fecundação prejudicam a função lútea aumentando o intervalo entre estros (DIEKMAN e GREEN, 1992). 
No presente estudo, o grupo de ratas que recebeu a S. lycocarpum durante o período de pré-implantação apresentou aumento no consumo de ração no $9^{0}$ e no $14^{0}$ dias de gestação. Tal fato não parece estar associado à administração da planta já que, nestes dias, as fêmeas não estavam mais consumindo a planta. Além disso, este aumento não influenciou no desenvolvimento da gestação, pois o peso e o ganho de peso destas fêmeas não apresentaram alterações. Por outro lado, este mesmo grupo apresentou redução no consumo de água no $4^{\underline{0}}$ dia de gestação, quando ainda estava consumindo a planta na ração, o que pode indicar um leve sinal de toxicidade causado pela administração da S. lycocarpum.

A administração da S. lycocarpum, tanto no período de préimplantação quanto no período de organogênese, não provocou alterações de peso e ganho de peso das fêmeas gestantes, indicando que o consumo da planta, nesta concentração, não causa toxicidade materna, que possa prejudicar diretamente o concepto.

A administração da S. lycocarpum durante o período de préimplantação não alterou nenhum dos parâmetros avaliados no desenvolvimento reprodutivo, indicando que nem o processo de transporte do embrião, nem o de implantação foram afetados pela planta.

Durante a prenhez se estabelece uma estreita interação entre o organismo materno e o concepto. Adaptações fisiológicas no organismo materno são observadas durante a prenhez como, por exemplo, aumento de até $50 \%$ no volume plasmático, sumento de 30-50\% no débito cardíaco, redução da resistência vascular sistêmica, aumento da ventilação pulmonar, 
aumento de até $50 \%$ na taxa de filtração glomerular e mudanças no metabolismo mineral (PARISI e CREASY, 1992). O desenvolvimento da placenta é outro exemplo de mudança associada a prenhez, uma vez que é um órgão temporário formado unicamente para atender a funções específicas durante a gestação como, por exemplo, transporte de alimentos, trocas gasosas, metabolização de substâncias endógenas, biotransformação de substâncias exógenas, proteção a relativo isolamento do concepto para evitar rejeição (CARNEY, 1997; BERNARDI, 1999).

No presente trabalho obervou-se redução do peso da placenta no grupo que recebeu a planta durante o período de organogênese. Este achado sugere efeito tóxico da $S$. lycocarpum administrada durante este período, porém não suficientemente intenso para causar toxicidade fetal, caracterizada, por exemplo, por redução de peso ao nascimento.

GUERRA et al. em 1997, administrando uma solução aquosa do polvilho da lobeira 2 vezes ao dia entre o $8^{0}$ e o $15^{0}$ dias de gestação de ratas, também não observaram efeitos tóxicos sobre as mães. Por outro lado, os fetos do sexo masculino apresentaram alterações de desenvolvimento, caracterizadas por filhotes menores, pesos maiores de placentas e pesos menores fígados.

A administração da S. lycocarpum durante a organogênese, no presente trabalho, promoveu o aparecimento de maior número de fetos do sexo feminino. Uma possível explicação para estes achados envolve o conhecimento de como ocorre a determinação do sexo em mamíferos. Assim, sabe-se que no momento da fertilização ocorre a determinação 
sexual genética e em machos o antígeno $\mathrm{H}-\mathrm{Y}$ induz a diferenciação da gônada em testículo, enquanto a ausência deste fator organizacional resulta na formação do ovário (GORDON e RUDDLE, 1981). Subseqüentemente, o testículo fetal produz testosterona e outros fatores que causam desenvolvimento do trato masculino e regressão do trato feminino. A ausência destes sinais endócrinos resulta na persistência do trato feminino e a regressão do trato masculino (WILSON et al., 1981). A diferenciação da genitália externa masculina está sob a influência da $5 \alpha$-diidrotestosterona (DHT) e, desta forma, qualquer mecanismo que cause redução da concentração deste hormônio no período crítico da diferenciação, pode induzir ao desenvolvimento anormal da genitália externa (NEUBERT, 1997). Um exemplo é a inibição da $5 \alpha$-redutase pela finasterida, o que causa a inibição da conversão da testosterona a DHT (CLARK et al., 1990, 1993). A síndrome clínica da deficiência da $5 \alpha$-redutase em pacientes humanos do sexo masculino causa pseudo-hermafroditismo (IMPERATO-McGINLEY et al., 1992). Em filhotes machos expostos in utero à finasterida são observadas malformações distintas e típicas como conseqüência da redução dos níveis de DHT, tais como: redução da distância anogenital e redução do peso da próstata. Nenhuma malformação é observada em filhotes fêmeas e nenhum outro defeito estrutural grosseiro é observado nos machos (CLARK et al., 1990).

Assim sendo, uma das possíveis explicações para o aumento do número de filhotes fêmeas pode ser uma redução da distância anogenital de filhotes machos, causada por alterações hormonais produzidas por 
substâncias presentes na planta, o que levaria a um erro na sexagem dos filhotes, traduzido por aumento aparente da prole feminina. Por outro lado, não foram observadas alterações na proporção entre machos e fêmeas por mãe, o que significa, talvez, que o aumento no número de fêmeas possa ser decorrência do maior número de filhotes nascidos no grupo que recebeu a planta durante a organogênese (107 filhotes), quando comparado ao número total de filhotes do grupo controle (81 filhotes).

No presente trabalho, ao exame visual da prole de ratas expostas à $S$. lycocarpum, na proporção de 3\% na ração, durante o período de préimplantação, verificou-se uma fêmea com encurtamento de membros, que ao exame esquelético apresentou várias alterações ósseas.

A prole de ratas expostas à S. lycocarpum durante o período de préimplantação apresentou, ainda, maior freqüência dos pontos de hemorragia no bulbo olfatório ao exame visceral.

A análise esquelética dos fetos revelou que a administração da $S$. lycocarpum durante a organogênese causou aumento da freqüência de esternébrios assimétricos nos filhotes.

Tais alterações sugerem que a planta apresenta um potencial teratogênico, que pode ser atribuído à presença de glicoalcalóides na planta, porém estudos mais aprofundados destes alcalóides, além da utilização de concentrações maiores da planta podem auxiliar na confirmação destas hipóteses.

Tomando estes dados em conjunto, pode-se sugerir que a administração da S. lycocarpum à 3\% na ração causa efeitos tóxicos em 
ratas adultas e na prole, principalmente quando exposta durante o período de organogênse. 


\section{CONCLUSÕES}

- A administração de S. lycocarpum a 3\% na ração de ratas, por 36 dias promoveu o aparecimento de efeitos tóxicos, caracterizado principalmente por redução de peso corpóreo e peso do fígado.

- Em machos, a administração de S. lycocarpum a 3\% na ração, por 60 dias, não produziu toxicidade.

- O consumo de S. lycocarpum a 3\% durante a gestação não promove toxicidade materna, porém alguns efeitos tóxicos são observados principalmente na prole exposta durante o período de organogênese. 


\section{REFERÊNCIAS}

ADAMS, N. R. Detection of the effects of phytoestrogens on sheep and cattle. Journal of Animal Science, v. 73, p. 1509-1515, 1995.

ADAMS, R. R. Phytoestrogens. In: CHEEKE, P.R. Toxicants of plant origin, vol. IV: phenolics. Boca Raton: CRC Press, 1989. p. 23-51.

ALIVERTI, V.; BONANOMI, L.; GIAVINI, E. The extent of fetal ossification as an index of delayed development in teratogenic studies on the rat. Teratology, v.20, p.237-42, 1979.

AMES, B. C. Dietary carcinogens and anticarcinogens. Science, v.221. p.1256-64, 1983.

BERNARDI, M. M. Exposição aos medicamentos durante o período perinatal. In: SPINOSA, H.S.; GÓRNIAK, S.L.; BERNARDI, M.M. Farmacologia aplicada ‘a medicina veterinária. 2. ed. Rio de Janeiro: Editora Guanabara Koogan S.A., 1999. p. 566-574.

BINNS, W.; SHAPE, J. L.; KEELER, R. J.; JAMES, L. F. Chronodlogic evaluation of teratogenicity in sheep fed Veratrum caflifornicum. J Amer Vet Med Assoc, v. 147, p.839-842, 1965.

BLANKEMEYER, J. T.; STRINGER, B. K.; RAYBURN, J. R.; BANTLE, J. A.; FRIEDMAN, M. Effects of potato alkaloids $\alpha$-chaconine and $\alpha$-solanine on membrane potential of frog embryos. J. Agric. Food Chem, v. 40, p. 2022-2025, 1992

BLANKEMEYER, J. T.; ATHERTON, R.; FRIEDMAN, M. Effect os potato glycoalkaloids $\alpha$-chaconine and $\alpha$-solanine on sodium active transport in frog skin. Journal of Agricultural and Food Chemistry, v.43, p. 636-639, 1995.

BLANKEMEYER, J. T., MCWILLIAMS, M. L., RAYBURN, J. R., WEISSENBERG, M., FRIEDMAN, M. Developmental toxicology of solamargine and solasonine glycoalkaloids in frog embryos. Food and Chemical Toxicology , v. 36, p.383-389, 1998.

BRUNETON, J. Plantas tóxicas. Vegetales peligrosos para el hombre y los animales. Zaragoza: Acribia, 2001. p.447-482.

CALDWELL, K. A.; GROSJEAN, O. K.; HENIKA, P. R.; FRIEDMAN, M. Hepatic ornithine decarboxylase induction by potato glycoalkaloids in rats. Food and Chemical Toxicology, v. 29, p. 531-535, 1991. 
CARNEY, E. W. Maternal physiological disruption. In: KAVLOCK, R. J.; DASTON, G. P. Drug toxicity in embryonic development I. Germany: Springer-Verlag Berlin Heidelberg, 1997. p. 573-594.

CHANG, M. C.; GU, Z.; SAKSENA, S. K. Effects of gossypol on the fertility of male rats, hamster and rabbits. Contraception, v. 21, p. 461-469, 1990.

CLARK, R. L.; ANTONELLO, J. M.; GROSSMAN, S. J.; WISE, L. D.; ANDERSON, C.; BAGDON, W. J.; PRAHALADA, S.; MacDONALD, J. S.; ROBERTSON, R. T. External genitalia abnormalities in male rats exposed in utero to finasteride, a $5 \alpha$-redutase inhibitor. Teratology, v. 42, p. 91-100, 1990.

CLARK, R. L.; ANDERSON, C. A.; PRAHALADA, S.; ROBERTSON, R. T.; LOCHRY, E. A., LEONARD, Y. M.; STEVENS, J. L.; HOBERMAN, A. M. Critical developmental periods for effects on male rat genitalia induced by finasteride, a $5 \alpha$-redutase inhibitor. Toxicology and Applied Pharmacology, v. 1139, p. 34-40, 1993.

COLTRAN, R. S.; KUMAR, V.; ROBBINS, S. L. Phatologic basis of disease. $5^{\text {th }}$ ed. USA: Saunders Company, 1994.

CRAWFORD, L.; KOCAN, R. M. Steroidal alkaloid toxicity to fish embryos. Toxicology Letters, v.66, p.175-81, 1993.

CRUZ, G. L. Dicionário das plantas úteis do Brasil. 3. ed. Rio de Janeiro: Civilização Brasileira, 1985. 360 p.

DALL'AGNOL, R.; VON POSER, G. L. The use of complex polysaccharides in the management of metabolic diseases: the case of Solanum lycocarpum fruits. Journal of Ethnopharmacology. v. 71, p. 337-341, 2000.

DIEKMAN, M. A.; GREEN, M. L. Mycotoxins and reproduction in domestic livestock. Journal of Animal Science, v. 70, p. 1615-1627, 1992.

DORIA FILHO, U. Introdução à bioestatística para simples mortais. São Paulo, Negócios, 1999. 152p.

FRIEDMAN, M. Composition and safety evaluation of potato berries, potato and tomato seeds, potatoes, and potato alkaloids. In: FINLEY, J. W.; ROBINSON, S.; ARMSTRONG, A. Food Safety Evaluation. Washington: American Chemical Society, 1992, p. 429-462.

FRIEDMAN, M.; HENIKA, P. R.; MACKEY. Feeding of potato, tomato and eggplant alkaloids affects food consumption and body and liver weights in mice. Journal of nutrition, v. 126, p. 989-999, 1996. 
GORDON, J. W.; RUDDLE, F. H. Mammalian gonadal determination and gametogenesis. Science, v. 211, p. 1265-1271, 1981.

GRAPHPAD. GraphPad Instat v2.10. San Diego: GraphPad software, 1993. (1 computer disk, 31/2 in, IBM).

GUERRA, M. O.; REIS, J. E. P.; OLIVEIRA, L. E. G.; PETERS, V. M. Avaliação do potencial teratogênico do fruto de lobeira (Solanum grandiflorum), administrado no período de organogênese do rato. Boletim do Centro de Biologia da Reprodução, UFJF, v.16, p.5256, 1997.

HARAGUCHI, M., UCHIMURA, R. T., MOTIDOME, M., GOTTLIEB, O. Aproveitamento dos esteróides dos frutos da lobeira. Ciência e Cultura, v.32, p.81-82, 1978.

HAYES, J. R.; CAMPBELL, T. C. Food additives and contaminants. In: KLAASSEN, C.D.; AMDUR, M.O.; DOULL, J. Casarett and Doull's Toxicology. The basic science of poisons. 3. ed. New York: Macmillan Publishing Company, 1986. p.796-7.

HSU, S. H.; TSAI, T. R.; LIN, C. N.; YEN, M. H.; KUO, K. W. Solamargine purified from Solanum incanum Chinese Herb Triggers gene expression of human TNFR I which may lead to cell apoptosis. Biochemical and Biophysical Research Communications, v. 229, p. 1-5, 1996.

IMPERATO-McGINLEY, J.; SANCHEZ, R. S.; SPENCER, J. R.; YEE, B.; VAUGHAN, E. D. Comparison of the effects of the $5 \alpha$-redutase inhibitor finasteride and the antiandrogen flutamide on prostate and genital differentiation: Dose-response studies. Endocrinology, v. 131, p. 1149-1156, 1992.

JADHAV, S.J., SHARMA, R.P., SALUNKHE, D.K. Naturally occurring toxic alkaloids in foods. CRC Critical Reviews in Toxicology, v. 9: 1, p. 21-104, 1981.

JAMES, L. F.; PANTER, K. E.; NIELSEN, D. B.; MOLYNEUX, R. J. The effect of natural toxins on reproduction in livestock. Journal of Animal Science, v.70, p. 1573-1579, 1992.

KEELER, R. F.; BAKER, D. C.; GAFFIELD, W. Spirosolane-containing Solanum species and induction of congenital craniofacial malformations. Toxicon, v.28, p.873-84, 1990.

KEELER, R. F.; BAKER, D. C.; GAFFIELD, W. Teratogenic Solanum species and the responsible teratogens. In: KEELER, R. G.; TU, A. T. 
Handbook of natural toxins. New York: Marcel Dekker, 1991, vol. 6, p. 83-97.

KELCE, W. R.; GRAY, L. E. Endocrine disruptors: Effects on sex steroid hormone receptors and sex development. In: KAVLOCK, R. J.; DASTON, G. P. Drug toxicity in embryonic development II. Germany: Springer-Verlag Berlin Heidelberg, 1997. p.435-474.

KERBER, V. A., MIGUEL, O. G., MOREIRA, E. A., GOMES, E. C., WEISS, F. A., VIEIRA, R. F. Avaliação quantitativa de alcalóides esteroidais em três espécies de Solanum Solanaceae ( $S$. grandfolium, $S$. lacerdae e S. lycocarpum), ênfase à solasodina. Revista Brasileira de Farmácia, v. 74, p. 67-69, 1993.

KISSMANN, K.G.; DORIS, G. Plantas infestantes e nocivas. v.3. São Paulo: BASF, 1995. p. 544-547.

LABOV, J.B. Phytoestrogens and mammalian reproduction. Comparative Biochemistry and Physiology, v.57, p.3-9, 1977.

LONG, G. G.; TUREK, J.; DIEKMAN, M. A.; SCHEIDT, A. B. Effect of zearalenone on days 7 to 10 post-mating on blastocyst development and endometrial morphology in sows. Veterinary Pathology, v. 29, p. 60-67, 1992.

LORENZI, H. Plantas daninhas do Brasil. 2. ed. Nova Odessa: Plantarum, 1991. 392p.

MANONAYAGI, S.; VANITHAKUMARI, G.; PADMA, S.; MALINI, T. Effects of bamboo buds: structural and functional changes in the epididymis of rats. Journal of Ethnopharmacology, v. 25, p. 201-212, 1989.

MANSON, J. M.; KANG, Y. J. Test methods for assessing female reprodutive and developmental toxicology. In: HAYS, A.W. Principles and methods of toxicology. 2 ed. New York: Raven Press. p. 311-360, 1989.

MATOS, F. J. A. Plantas medicinais. Guia de seleção e emprego de plantas medicinais do nordeste do Brasil. v.1. Fortaleza: IOCE, 1989. p.45-57.

McEVOY, T. G.; ROBINSON, J. J.; ASHWORTH, J. A.; ROOKE, J. A.; SINCLAIR, K. D. Feed and forage toxicants affecting embryo survival and fetal development. Theriogenology, v.55, p.113-129, 2001.

MOTIDOME, M.; LEEKNING, M. E.; GOTTLIEB, O. R. A química de solanáceas brasileiras. I - A presença de solamargina e de solasonina 
no juá e na lobeira. Anais da Academia Brasileira de Ciências, v.42, p.375-6, 1970.

NEUBERT, D. Vulnerability of the endocrine system to xenobiotic influence. Regulatory Toxicology and Pharmacology, v. 26, p. 9-29, 1997.

NISHIE, K.; GUMBMANN, M. R.; KEYL, A. C. Pharmacology of solanine. Toxicology and Applied Pharmacology, v.19, p.81-92, 1971.

ORGELL, W.H. Inhibition of human plasma cholinesterase in vitro by alkaloids, glycosides and other natural substance. Lloydia, v.26, p.3643, 1963.

PANTER, K. E.; KEELER, R. F.; JAMES, L. E.; BUNCH, T. D. Impact of plant toxins on fetal and neonatal development: A review. Journal of Range Manage, v. 45, p. 52-57, 1992.

PARISI, V. M.; CREASY, R. K. Maternal biologic adaptations to pregnancy. In: REECE, E. A.; HOBBINS, J. C.; MAHONEY, M. J.; PETRIE, R. H. Medicine of the fetus and mother. Philadelphia: Lippincot, 1992. p. 831-848.

PETERS, V. M.; ReIS, J. E. P.; OliveiRA, L. E. G.; GUERRA, M. O. Avaliação do potencial tóxico da lobeira (Solanum grandiflorum), administrado no período de implantação do blastocisto de rato. Boletim do Centro de Biologia da Reprodução, UFJF, v.16, p.4751, 1997.

PETERS, V. M.; PINHEIRO, N. L.; REIS, J. E. P.; GUERRA, M. O. Absence of interceptive effect in rats treated with Solanum lycocarpum (St. Hil). Contraception, v.63, p.53-55, 2001.

PIMENTEL, C. A.; BROD, C. L. G. P.; PIMENTEL, S. M.; MEDEIROS, E. L.; BENTO C. L. R.; MONKS, P. Hiperestrogenismo causado por fitoestrógenos em novilhas da raça holandesa. Revista Brasileira de Reprodução Animal, v.1, n.2, p. 15-20, 1977.

RENWICK, J. H.; CLARINGBOLD, D. B.; EARTHY, M. E.; FEW, J.D.; McLEAN, A. C. S. Neural-tube defects produced in Syrian hamsters by potato glycoalkaloids. Teratology, v. 30, p. 371-381, 1984.

RODDICK, J. G. The acetylcholinesterase-inhibitory activity of steroidal glycoalkaloids and their aglycones. Phytochemistry, v. 28, p. 26312634, 1989.

RODDICK, J. G., RIJENENBERG, A. L.; WEISSENBERG, M. Alterations to the permeability of liposome membranes by the solasodine-based 
glycoalkaloids solasonine and solamargine. Phytochemistry, v. 31, p. 151-154, 1992.

SÁ, R. C. S.; VIREQUE, A. A.; REIS, J. E. P.; GUERRA, M. O. Evaluation of the toxicity of Solanum lycocarpum in the reproductive system of male mice and rats. Journal of Ethnopharmacology, v.73, p.283-287, 2000.

SCAVONE, O.; PANIZZA, S. Plantas tóxicas. 2. ed. São Paulo: CODACUSP, 1981. p. 128.

STAPLES, R. E.; SCHENELL, V. L. Refinements in rapid clearing technic in the Koh-alizarin red $S$ method for fetal bone. Stain Technology, v.39, p.61-3, 1964.

STEVENS, K. R., GALLO, M. A. Practical considerations in the conduct of chronic toxicity studies. In: HAYES, A.W. Principles and methods of toxicology, 2nd ed. New York: Raven Press, 1989, p. 237-250.

STOB, M. Estrogens. In: RECHAGL, M. J. Handbook of naturally occuring food toxicants. Boca Raton: CRC Press, 1983. p. 81-100.

TOKARNIA, C. H. ; DÖBEREINER, J. ; PEIXOTO, P. V. Plantas tóxicas do Brasil. Rio de Janeiro: Editora Helianthus, 2000. 320p.

VAN GELDER, W. M. J. Chemistry, toxicology, and occurence of steroidal glycoalkaloids: potentialcontaminants of the potato. In: RIZK, A. F. Poisonous plants contaminating edible plants. Boca Raton: CRC, 1990, p. 117-156.

WILSON, J. D.; GOY, R. W.; PHOENIX, C. H. Hormones and sexual behavior. Science, v. 211, p. 1278-1284, 1981.

WILSON, J. G. Methods of administering agents and detecting malformations in experimental animals. In: WILSON, J. G.; WORKANY. Teratology Principles and Techniques, p. 262-277. USA: University of Chicago Press, 1965.

ZENICK, H.; CLEGG, E.D. Assessment of male reproductive toxicology: a risk assessment approach. In: HAYS, A.W. Principles and methods of toxicology. 2 ed. New York, Raven Press. p. 275-310, 1989. 